\title{
LA COLUSIÓN COMO UNA PRÁCTICA RESTRICTIVA DE LA COMPETENCIA QUE AFECTA GRAVEMENTE LOS PROCESOS DE SELECCIÓN DE CONTRATISTAS*
}

\section{COLLUSION AS A RESTRICTIVE PRACTICE THAT SERIOUSLY AFFECTS COMPETITION SELECTION PROCESS OF CONTRACTORS}

\author{
Deisy Galvis-Quintero** \\ Fecha de recepción: 6 de agosto de 2015 \\ Fecha de aceptación: 9 de diciembre de 2015 \\ Disponible en línea: 31 de mayo de 2016
}

\section{Para citar este artículo/To cite this article}

\author{
Galvis-Quintero, Deisy, La colusión como una práctica restrictiva de la \\ competencia que afecta gravemente los procesos de selección de contratis- \\ tas, 132 Vniversitas, 133-196 (2016). http://dx.doi.org/10.11144/Javeriana. \\ vj132.cprc \\ doi:10.11144/Javeriana.vj132.cprc
}

\footnotetext{
* El presente artículo es producto de los resultados de investigación en el marco del proyecto Los acuerdos colusorios en los procesos de selección de contratistas: una mirada desde el derecho de la competencia, del grupo de investigación en Derecho Comercial Colombiano y Comparado, perteneciente al Departamento de Derecho Comercial de la Universidad Externado de Colombia.

** Abogada, Universidad Externado de Colombia. Magíster en derecho comercial, Universidad Externado de Colombia. Especialista en derecho comercial, Universidad Externado de Colombia. Especialista en derecho tributario, Universidad del Rosario. Se ha desempeñado como abogada del Grupo de Promoción de la Competencia de la Superintendencia de Industria y Comercio; abogada de la Subdirección de Regulación y Personas Jurídicas de la Secretaría Distrital de Cultura, Recreación y Deporte; asesora, Caja Promotora de Vivienda Militar y de Policía. En la actualidad, docente investigadora, Departamento de Derecho Comercial, Universidad Externado de Colombia; asesora, Dirección Regional Bogotá, Instituto Colombiano de Bienestar Familiar, ICBF. Socia de la firma Galvis Quintero \& Abogados Asociados S.A.S. Colombia. Contacto: deisy.galvis@uexternado.edu.co
} 


\section{RESUMEN}

El presente artículo constituye un acercamiento al tema de los acuerdos colusorios desde la perspectiva del derecho de la competencia, da una mirada a la interrelación entre la libre competencia y la contratación estatal, y destaca precisamente cómo el terreno público es el escenario en el que los acuerdos colusorios exhiben sus efectos más nocivos y por ende, cómo las normas de competencia pueden constituir una herramienta eficaz para la lucha contra este flagelo, todo ello en el marco de un adecuado equilibrio entre los principios de libre concurrencia y selección objetiva. La metodología empleada en esta investigación ha partido de un exhaustivo análisis de las principales resoluciones sobre la violación del artículo 9 del Decreto 2153 de 1992 expedidas por la Superintendencia de Industria y Comercio, y de algunos pronunciamientos sobre colusión, contratación estatal, acuerdos restrictivos de la competencia, libre competencia y derecho administrativo sancionador expedidos tanto por la jurisprudencia constitucional como por la administrativa, con especial mención de las normas legales aplicables a estas materias. Así mismo, se ha realizado un barrido general respecto de la doctrina nacional e internacional sobre estas materias, y de algunos de los estudios de organismos nacionales e internacionales sobre colusión, manipulación de licitaciones, transparencia y corrupción.

Palabras clave: Derecho de la competencia; licitación pública; colusión en licitaciones; contratación pública; acuerdos restrictivos de la competencia; clemencia; Estado consumidor; procesos de selección de contratistas; manipulación de licitaciones 


\section{ABSTRACT}

This study is an approach to bid-rigging agreements from the perspective of competition law, analyzing the interrelation between free competition and public procurement considering that the public sector is the place in which bid-rigging agreements show its harmful effects and how competition rules can be an effective tool in the fight against this scourge, all in the context of finding a proper balance between the principles of free competition and objective selection.

The methodology used in this research consists in an exhaustive analysis of the main resolutions issued by the Superintendency of Industry and Trade regarding the violation of Article 9 of Decree 2153 of 1992; the study of some constitutional and administrative court decisions in collusion, state procurement agreements, and restricted competition issues, and the study of the rules of law applicable to the aforementioned matters. Likewise, this research gives a general overview of domestic and international doctrine regarding the mentioned issues and of some studies conducted by national and international organizations regarding collusion, bid rigging, transparency and corruption.

Keywords: Competition Law; public tenders; bid rigging; government procurement; agreements restricting competition; leniency; State consumer; contractor selection processes

\section{SUMARIO}

Introducción.- I. La colusión en Colombia. Definición y ámbito de APLiCACión.- $A$. Un acuerdo entre dos o más sujetos.- B. Que el acuerdo tenga por objeto la colusión en licitaciones o concursos o como efecto la distribución de adjudicaciones de contratos, distribución de concursos o fijación de los términos de las propuestas. - 1 . O que el acuerdo tenga por objeto la colusión en las licitaciones o concursos.- 2. O que el acuerdo tenga como efecto la distribución de adjudicaciones de contratos, distribución de concursos o fijación de términos de las propuestas.- C. Que dicho acuerdo afecte el bien jurídico protegido.- II. FORMAS MÁS COMUNES DE Colusión.- A. Supresión de la oferta (bid suppression). B. Ofertas complementarias o de resguardo (complementary bidding, cover bidding $o$ "courtesy" bidding).- C. Rotación de ofertas (bid rotation).- D. Acuerdo de precios.- E. Acuerdos de reparto o asignación de mercado.- F. Subcontratación (subcontracting).- III. CIRCUNSTANCIAS QUE PUEDEN PROPICIAR LA CONSOlidación de ACUerdos COlusorios.- IV. PRueba del aCuerdo COlusorio. La utilización de indicios.- V. Algunas medidas Que han IMPLEMENTADO LOS ESTADOS PARA HACER FRENTE A LA COLUSIÓN EN LOS PROCESOS DE SELECCIÓN DE CONTRATISTAS. - CONCLUSIONES.- Bibliografía. 


\section{INTRODUCCIÓN}

Con la adopción del modelo de Estado Social de Derecho en la Constitución de 1991, se incorporó también en la Constitución Económica el modelo de economía social de mercado ${ }^{1}$, en virtud del cual se reconocen en cabeza de los ciudadanos las libertades económicas desarrolladas expresamente en el artículo 333 de la Constitución Política ${ }^{2}$, estas son: la libertad de empresa e iniciativa privada y la libre competencia.

La libertad de empresa también denominada como libre iniciativa privada", se concibe como aquella "libertad que se reconoce a los ciudadanos para afectar o destinar bienes de cualquier tipo (principalmente de capital) para la realización de actividades económicas para la producción e intercambio de bienes y servicios conforme a las pautas o modelos de organización típicas del mundo económico contemporáneo con vistas a la obtención de un beneficio o ganancia. El término empresa en este contexto parece por lo tanto cubrir dos aspectos, el inicial - la iniciativa o empresa como manifestación de la capacidad de emprender y acometer - y el instrumental - a través de una organización económica típica-, con abstracción de la forma jurídica (individual o societaria) y del estatuto jurídico patrimonial y laboral"'. También implica tanto la libertad contractual - es decir, la capacidad de celebrar los acuerdos que sean necesarios para el desarrollo de la actividad económica- como la libre iniciativa privada ${ }^{5}$.

1 En su sentencia C-865-04, la Corte Constitucional define la economía social de mercado como el modelo "según el cual las reglas de la oferta y la demanda deben estar al servicio del progreso y desarrollo económico de la Nación". Corte Constitucional, Sentencia C-865-04, 7 de septiembre de 2004, magistrado ponente Rodrigo Escobar-Gil. Disponible en: http://www. corteconstitucional.gov.co/relatoria/2004/c-865-04.htm

2 Colombia, Constitución Política, segunda edición corregida, 116 Gaceta Constitucional, 20 de julio de 1991, artículo 333. Disponible en: http://www.secretariasenado.gov.co/senado/ basedoc/constitucion_politica_1991.html

3 Corte Constitucional, Sentencia C-228-10, 24 de marzo de 2010, magistrado ponente Luis Ernesto Vargas-Silva. Disponible en: http://www.corteconstitucional.gov.co/relatoria/2010/c-228-10. htm

4 Martín Bassols-Coma, Constitución y sistema económico (Tecnos, Madrid, 1988) citado por la Corte Constitucional, Sentencia C-524-95, 16 de noviembre de 1995, magistrado ponente Carlos Gaviria-Díaz. Disponible en: http://www.corteconstitucional.gov.co/relatoria/1995/C-524-95. htm

5 Corte Constitucional, Sentencia C-228-10, 24 de marzo de 2010, magistrado ponente Luis Ernesto Vargas-Silva. Disponible en: http://www.corteconstitucional.gov.co/relatoria/2010/c-228-10. htm 
Al tratar de la libre competencia, la Corte ha entendido que esta se presenta cuando "un conjunto de empresarios, en un marco normativo de igualdad de condiciones, ponen sus esfuerzos, factores empresariales y de producción, en la conquista de un mercado determinado, bajo el supuesto de la ausencia de barreras de entrada o de otras prácticas restrictivas que dificulten el ejercicio de una actividad económica lícita". Se trata de un principio estructural de la economía social del mercado, que comprende al menos tres prerrogativas: 1) la posibilidad de ejercer una actividad económica libre, con las excepciones y restricciones establecidas por la ley, 2) la libertad para ofrecer las condiciones y ventajas comerciales que estimen oportunas, y 3) la libertad de los consumidores o usuarios para contratar?

En desarrollo de ese modelo de economía social de mercado, se ha definido la libre competencia como un derecho que debe perseguir una función social en el marco del Estado Social de Derecho - obligación que también se les ha impuesto a la empresa y, en general, a la iniciativa privada ${ }^{8}$ - En estos términos se reconoce la importancia de fomentar la actividad empresarial, pero resaltando a su vez la imperiosa necesidad de que el Estado utilice los instrumentos que resulten aconsejables para intervenir en la economía, a fin de evitar y controlar los abusos que se puedan presentar en el mercado, incentivar la competencia, proteger los bienes y valores constitucionales ${ }^{9}$, conciliar los intereses particulares y generales presentes en la libre competencia, y proteger los derechos de los consumidores.

6 Corte Constitucional, Sentencia C-992-06, 29 de noviembre de 2006, magistrado ponente Álvaro Tafur-Galvis. Disponible en: http://www.corteconstitucional.gov.co/relatoria/2006/c-992-06. $\mathrm{htm}$

7 Corte Constitucional, Sentencia C-616-01, 13 de junio de 2001, magistrado ponente Rodrigo Escobar-Gil. Disponible en: http://www.corteconstitucional.gov.co/relatoria/2001/c-616-01. htm

8 Corte Constitucional, Sentencia C-228-10, 24 de marzo de 2010, magistrado ponente Luis Ernesto Vargas-Silva. Disponible en: http://www.corteconstitucional.gov.co/ relatoria/2010/c-228-10.htm. Corte Constitucional, Sentencia C-263-11, 6 de abril de 2011, magistrado ponente Jorge Ignacio Pretelt-Chaljub. Disponible en: http://www.corteconstitucional.gov.co/relatoria/2011/c-263-11.htm

9 Corte Constitucional, Sentencia C-228-10, 24 de marzo de 2010, magistrado ponente Luis Ernesto Vargas-Silva. Disponible en: http://www.corteconstitucional.gov.co/ relatoria/2010/c-228-10.htm. Corte Constitucional, Sentencia C-263-11, 6 de abril de 2011, magistrado ponente Jorge Ignacio Pretelt-Chaljub. Disponible en: http://www.corteconstitucional.gov.co/relatoria/2011/c-263-11.htm 
Ahora, refiriéndonos al contenido mismo del derecho a la libre competencia económica, debemos indicar que al ser un derecho individual y a la vez colectivo ${ }^{10}$, su desarrollo involucra tanto intereses particulares como generales. Así, de una parte se busca alcanzar un estado de sana competencia en el que los empresarios en igualdad de condiciones puedan ingresar al mercado y obtener un lucro económico y, de otra, se busca la protección del mercado de manera tal que no se vea falseado por barreras artificiales, por abuso de la posición de dominio o por actos o acuerdos restrictivos de la competencia, todo ello en el marco de la debida protección de los derechos de los consumidores (sean estos particulares o el Estado), los cuales no buscan otra cosa que la obtención de bienes y servicios de la mejor calidad al mejor precio posible ${ }^{11}$. De esa manera se garantiza "tanto el interés de los competidores, el colectivo de los consumidores y el interés público del Estado"12.

En ese contexto, la libre competencia económica no solamente propugna por garantizar una sana competencia en el mercado, sino también por impulsar la existencia de una pluralidad de oferentes $^{13}$, para que se haga efectivo el derecho a la libre elección de

10 Colombia, Constitución Política, segunda edición corregida, 116 Gaceta Constitucional, 20 de julio de 1991, artículo 88. Disponible en: http://www.secretariasenado.gov.co/senado/basedoc/ constitucion_politica_1991.html

11 Esta afirmación constituye una máxima general. Se exceptúan los procesos de escogencia de consultores, cuya modalidad de selección es el concurso de méritos y no el factor precio. En efecto, el artículo 5, numeral 4, inciso 2, de la Ley 1150 de 2007 establece: “...En ningún caso se podrá incluir el precio, como factor de escogencia para la selección de consultores". Colombia, Ley 1150 de 2007, por medio de la cual se introducen medidas para la eficiencia y la transparencia en la Ley 80 de 1993 y se dictan otras disposiciones generales sobre la contratación con recursos públicos, 46.691 Diario Oficial, 16 de julio de 2007. Disponible en: http://www.secretariasenado.gov.co/senado/basedoc/ley_1150_2007.html. Así mismo, respecto a la escogencia de la oferta más favorable para la entidad, deberá aplicarse lo señalado en el artículo 5 de la Ley 1150 de 2007, modificado por el artículo 88 de la Ley 1474 de 2011. Colombia, Ley 1474 de 2011, por la cual se dictan normas orientadas a fortalecer los mecanismos de prevención, investigación y sanción de actos de corrupción y la efectividad del control de la gestión pública, Estatuto Anticorrupción, 48.128 Diario Oficial, 12 de julio de 2011. Disponible en: http://www.secretariasenado.gov.co/senado/basedoc/ley_1474_2011. $\mathrm{html}$

12 Corte Constitucional, Sentencia C-815-01, 2 de agosto de 2001, magistrado ponente Rodrigo Escobar-Gil. Disponible en: http://www.corteconstitucional.gov.co/relatoria/2001/c-815-01. htm

13 Esta afirmación encuentra su sustento en la lógica misma de los procesos de selección para la contratación estatal consagrados en el Estatuto General de la Contratación de la Administración Pública, comoquiera que establece la regla general de la licitación pública como mecanismo de escogencia de los contratistas del Estado. Ahora bien, las demás modalidades de selección encuentran su sustento en la libertad de configuración del legislador, bajo el designio de satisfacción de las necesidades de la administración, siguiendo otros procesos 
los consumidores ${ }^{14}$, máxime cuando ese consumidor es el propio Estado, caso en el cual estamos en presencia de un interés general que necesariamente debe ser salvaguardado.

En efecto, cuando el Estado concurre al mercado en la búsqueda de bienes y servicios por medio de un proceso contractual (compras públicas ${ }^{15}$ ), lo hace como un consumidor más; sin embargo, a diferencia de los particulares, la formación de su voluntad no atiende a una mera liberalidad de designio, sino que está reglada y se construye mediante el seguimiento de etapas o formas enmarcadas en diversas modalidades de selección de contratistas; siempre bajo el imperio del deber de selección objetiva ${ }^{16}$, para la escogencia de la otra parte contratante.

Así pues, en la noción de contrato estatal se predica y concibe la autonomía de la voluntad como presupuesto para la generación de obligaciones y derechos, entendiendo que el Estado en esta relación constituye una parte cualificada, por tanto su voluntad debe advertir el cumplimiento de las formas de selección establecidas y todo el entramado formal y sustancial que subyace y conforma a cada una de ellas. Amén de lo expuesto, este deber de selección objetiva se predica tanto para las entidades estatales sometidas al

distintos al de la licitación pública, bajo criterios de simplificación de procedimientos, por ejemplo, la selección abreviada o el valor de la contratación, verbigracia la contratación de mínima cuantía en los términos del artículo 94 de la Ley 1474 de 2011, o la especialidad del objeto a contratar, por ejemplo, el concurso de méritos o la contratación directa, entre otros. De otra parte, en este apartado es preciso indicar que en apego máximo a lo establecido en el Estatuto General de Contratación de la Administración Pública, entre los procesos de selección de contratistas existe plena posibilidad de que la administración contrate con un oferente único, obviamente, si se cumplen los siguientes presupuestos: 1). Que dentro del proceso de selección se hayan respetado materialmente todas las etapas legalmente preceptuadas -en especial la de publicidad-, en procura de lograr el interés y la participación de oferentes y; 2). que a pesar de haber cumplido lo anterior, solo se haya presentado una única oferta $y$, esta cumpla tanto los aspectos habilitantes como los ponderables del caso, establecidos en los pliegos de condiciones. Colombia, Ley 80 de 1993, por la cual se expide el Estatuto General de Contratación de la Administración Pública, 41.094 Diario Oficial, 28 de octubre de 1993. Disponible en: http://www.secretariasenado.gov.co/senado/basedoc/ley_0080_1993.html

14 Corte Constitucional, Sentencia C-815-01, 2 de agosto de 2001, magistrado ponente Rodrigo Escobar-Gil. Disponible en: http://www.corteconstitucional.gov.co/relatoria/2001/c-815-01. htm

15 "Es la adquisición de bienes y servicios que el Estado realiza al sector privado para su debido funcionamiento y el cumplimiento de sus fines". Disponible en: http://www.yocomprocolombiano.com/wp-content/uploads/2014/03/abc_compraspublicas_2012_screen.pdf

16 Colombia, Ley 1150 de 2007, por medio de la cual se introducen medidas para la eficiencia y la transparencia en la Ley 80 de 1993 y se dictan otras disposiciones generales sobre la contratación con recursos públicos, 46.691 Diario Oficial, 16 de julio de 2007, artículo 5. Disponible en: http://www.secretariasenado.gov.co/senado/basedoc/ley_1150_2007.html 
Estatuto General de Contratación Estatal como para aquellas que por expresa disposición de este, escapan a su regulación ${ }^{17}$.

Pues bien, precisamente uno de los aspectos que inciden en mayor grado en la formación de la voluntad de las entidades estatales es la garantía de cumplimiento de los principios de transparencia, economía, responsabilidad, igualdad, buena fe (Ley 80 de 1993) y eficiencia (Ley 1150 de 2007); así mismo, se enuncia la obligatoriedad de aplicación de lo que JuAn CARlos Expósito denomina la zona común de la contratación estatal ${ }^{18}$, refiriéndose al mandato establecido en el artículo 14 de la Ley 1150 de 2007, que estatuye el deber de aplicación - tanto para las entidades sometidas al Régimen de Contratación de la Administración Pública como para aquellas que no lo están - de los artículos 209 (principios de la función administrativa) y 269 (normas de la gestión fiscal) de la Constitución Política, así como el régimen de inhabilidades e incompatibilidades establecido en el bloque de legalidad que las precisa ${ }^{19}$.

Lo anterior, dentro del marco de una libre competencia entre los oferentes y con el propósito de seleccionar la oferta más favorable ${ }^{20}$

17 José Pascual-García señala: "Se ha convertido en un lugar común en los estudios de Derecho público utilizar la expresión 'huida del Derecho administrativo' para referirse a las consecuencias de la creación de distintas fórmulas organizativas en el ámbito del sector público que, pese a perseguir fines de interés general, su personalidad es privada o que, aun ostentando la condición de organismo público, se rigen en mayor o menor medida por el derecho privado". José Pascual-García, La huida del derecho administrativo, del presupuesto y de los controles financieros por los nuevos entes del sector público, 3 Revista Presupuesto y Gasto Público, Instituto de Estudios Fiscales, IEF, 109-128, 110 (2010). Disponible en: http://www.ief.es, http:// www.ief.es/documentos/recursos/publicaciones/revistas/presu_gasto_publico/60_07.pdf. Precisamente, la materialización de esta tan conocida expresión de huida del derecho administrativo es la que se denota en la excepcionalidad de aplicación del Estatuto de Contratación Estatal a un sinnúmero de entidades estatales. Sobre el particular, nos permitimos citar en extenso al profesor Ernesto Matallana-Camacho, que sintetiza las entidades que cuentan con un régimen contractual excepcional. Entre ellas: las universidades estatales, el Banco de la República, las empresas prestadoras de servicios públicos domiciliarios, algunas entidades del sector defensa, entre otras. Ernesto Matallana-Camacho, Manual de Contratación de la Administración Pública, 251-252 ( $3^{\text {a }}$ edición, Universidad Externado de Colombia, Bogotá, 2013).

18 Juan Carlos Expósito-Vélez, El deber de selección objetiva, en Contratación estatal. Estudios sobre la reforma del estatuto contractual. Ley 1150 de 2007, 121-162, 139 (José LuIs BeNAvides \& Jaime Orlando Santofimio, comps., Universidad Externado de Colombia, Departamento de Derecho Administrativo, Bogotá, 2009).

19 Las consagradas en la Ley 80 de 1993 o Estatuto General de Contratación de la Administración Pública, la Ley 1474 de 2011 o Estatuto Anticorrupción, y la Ley 734 de 2002 o Código Disciplinario Único, entre otras normas.

20 Artículo 5 de la Ley 1150 de 2007, modificado por el artículo 88 de la Ley 1474 de 2011. Artículo 2.2.1.1.2.2.2. del Decreto 1082 de 2015. 
a los intereses de la administración y a los fines que esta pretende alcanzar $^{21}$.

Conforme lo venimos afirmando, las normas de contratación pública y aquellas de la zona común aludidas anteriormente buscan que la selección del contratista sea resultado de un análisis objetivo de las propuestas, desprovisto de consideraciones subjetivas por parte de los funcionarios encargados del proceso de selección y libre de la posible manipulación de los propios oferentes; esto con el propósito de que la oferta escogida sea la más favorable a las necesidades planteadas por la administración al momento de contratar. Sin embargo, como se verá, no siempre se puede lograr ese equilibrio entre las normas de competencia y las que rigen la contratación estatal, pues en ocasiones con el ánimo de salvaguardar unas, puede ponerse en peligro la aplicación de las otras.

Se advierte entonces, que un proceso contractual se desvía del cumplimiento del deber de selección objetiva, tanto si los funcionarios encargados de la selección atienden a criterios subjetivos para escoger al contratista, o desconocen los principios que rigen la contratación estatal, como si los propios oferentes utilizan estrategias, artimañas o formas similares para manipular el proceso contractual o renuncian a competir entre sí, por lo cual ya no estamos ante un juego competitivo en que los oferentes van a tratar de demostrar que son la oferta más favorable para la entidad, sino en un escenario en el que la propuesta ganadora será aquella respecto de la cual los oferentes se han puesto de acuerdo, por ejemplo, sobre quién va a ser el ganador, cómo van a lograrlo y cómo van a repartirse los beneficios consecuentes; todo esto en contravía de los postulados normativos y axiológicos que gobiernan la contratación del Estado, lo cual necesariamente incidirá en el costo final de esos bienes y servicios $^{22}$ que pretende contratar la Administración y, en últimas,

21 Artículo 2 de la Constitución Política y artículo 3 de la Ley 80 de 1993 modificado por el artículo 32 de la Ley 1150 de 2007.

22 En palabras de Ángel Gurría, Secretario General de la OCDE, "las experiencias en los países de la OCDE revelan que los cárteles pueden aumentar el costo de los bienes y servicios en $20 \%$ o más. Las primeras víctimas de un cártel son los clientes del mismo. Cuando esos clientes son los organismos públicos, los cárteles perjudican a los contribuyentes y por tanto a la economía en su conjunto". Organización para la Cooperación y el Desarrollo Económicos, OCDE, Secretaría General, Memorándum de entendimiento entre la OCDE, la CFC y el IMSS para la implementación de las directrices del Comité de Competencia de la OCDE para combatir la colusión en las licitaciones para las compras públicas, Palabras de Ángel Gurría, Secretario General de la OCDE, México, 13 de enero de 2011. Disponible en: http://www.oecd. 
en el interés general entendido como la satisfacción de la necesidad que se pretende alcanzar con la contratación del bien o servicio.

Lo anterior es lo que la doctrina ha denominado bid rigging o collusive tendering, que se presenta comúnmente en los procesos contractuales en que dos o más empresas llamadas a luchar para obtener la adjudicación de un contrato deciden aliarse para no hacerlo. El acuerdo puede presentarse de diversas formas pero siempre estará enfocado en lograr la adjudicación concertada o el favorecimiento de uno de los participantes de la colusión. De igual forma, los mismos pueden presentarse con la aquiescencia o no de los funcionarios públicos encargados del proceso de contratación, pero siempre tendrán como resultado no solamente una restricción indebida a la libre competencia — lo que a su vez puede acarrear un incremento significativo en los precios de los bienes y servicios contratados - sino una disminución en la percepción de transparencia del proceso contractual ${ }^{23}$, por parte no solo de los demás proponentes sino de la ciudadanía en general $^{24}$.

org/centrodemexico/medios/cooperacionocde-cfc-imss.htm

23 Según el Latin American Public Opinion Project, LAPOP, Barómetro Global de la Corrupción 2014 (http://www.vanderbilt.edu/lapop/), Colombia ocupa el segundo puesto con mayor corrupción entre 25 países con 79,6 puntos, en una escala de 0 a 100 puntos; según Transparencia Internacional, en 2014 Colombia ocupó nuevamente el puesto 94 en el Índice de Percepción de Corrupción 2014 (http://www.transparency.org/cpi2014/results) entre 175 países evaluados y, de acuerdo a la Cuarta encuesta nacional de prácticas contra el soborno en empresas colombianas, se encontró que de los empresarios encuestados en 2014, el 91\% percibe que en su entorno de negocios se ofrecen sobornos, lo que si bien implica una mejora porcentual de $3 \%$ respecto de 2012, también refleja, en palabras del informe, "un claro panorama de la ausencia de programas concretos que articulen valores, políticas y procedimientos que ayuden a mitigar este fenómeno en todas las actividades de gestión empresarial para lograr entornos íntegros y transparentes en la forma de hacer negocios", esto considerando que el 76\% de los empresarios cree que el cierre de negocios y/o contratos es la forma más frecuentemente utilizada para sobornar, siendo común la realización de pagos para agilizar o facilitar trámites (65\%), las contribuciones políticas (50\%), el soborno común (52\%), los regalos $(38 \%)$, los gastos de representación (29\%) y los patrocinios (24\%), entre otras formas. Así mismo, resulta alarmante que el $58 \%$ de los empresarios considere que de no pagar sobornos se pierden negocios: $17,3 \%$ es el promedio ponderado del valor del contrato que se paga de manera secreta para ganar la adjudicación. Datos tomados de Transparencia por Colombia, Universidad Externado de Colombia, Cuarta encuesta nacional sobre prácticas contra el soborno de empresas colombianas, 23 Cuaderno de Transparencia (2015). Disponible en: http://transparenciacolombia.org.co/es/ noticias/resultados-de-la-cuarta-encuesta-nacional-sobre-practicas-contra-el-soborno-enempresas-colombianas

24 “(...) La colusión en los procesos de selección con el Estado conlleva diversos efectos negativos en varios agentes, entre los que cabe resaltar los siguientes: (i) Otros proponentes, al limitarles la competencia y la participación en un proceso de selección justo y regido por los principios de igualdad de oportunidades y de transparencia; (ii) el Estado, por los costos monetarios y de transacción que representa la presencia de proponentes no idóneos en sus procesos de selección; (iii) el mercado, porque se reduce la competencia, se generan asimetrías de la información 
En ese orden de ideas, la contratación pública es el escenario en el cual los efectos de esta práctica concertada resultan mucho más dañinos por ser el Estado uno de los mayores consumidores de bienes y servicios - por ejemplo, en Colombia se calcula que las compras públicas constituyen entre el 5 y el $15 \%$ del PIB ${ }^{25}$ - Esto explica la importancia de este tema, no solamente para identificar la conducta sino para estudiar algunas de las herramientas de lucha contra este flagelo que han implementado otras legislaciones; estos puntos serán abordados a lo largo de este escrito.

Si bien la colusión se puede presentar en cualquier escenario de contratación, sus mayores efectos se proyectan en el proceso licitatorio, por ser este el procedimiento por el cual se llevan a cabo las adquisiciones de bienes y servicios de mayor envergadura ${ }^{26}$; además de que se trata de un procedimiento reglado, que por su propia estructura puede facilitar la conformación de estos acuerdos. Sin embargo, debemos resaltar que en Colombia, la colusión es un fenómeno que afecta indistintamente todos los procesos de selección.

Se trata de una infracción de doble vía, pues se afecta tanto el interés general que tiende a una libre competencia como el erario público ${ }^{27}$, pues los precios ya no van a ser el resultado de una puja

entre los proponentes e incluso se pueden elevar los precios de los bienes y servicios ofrecidos o reducirse su calidad; y (iv) la comunidad en general, por cuanto se afecta negativamente el bienestar social al darse una pérdida irrecuperable de eficiencia en el mercado por el aumento injustificado de las utilidades percibidas por los participantes coludidos". Superintendencia de Industria y Comercio, Resolución 40901 de 2012, 13.

25 Se calcula que en Brasil, Colombia, Ecuador, El Salvador, Guatemala, Honduras, Jamaica, Perú y otros países latinoamericanos, los gastos por adquisiciones representan entre el $5 \mathrm{y}$ el $15 \%$ del PIB (dependiendo de cómo se mida). Organización para la Cooperación y el Desarro1lo Económicos, OCDE, The Size of Government Procurement Markets (2011). Disponible en: http://www.oecd.org/newsroom/archives/1845927.pdf, citado en EDWArd WhiteHorn, Aumento de la competencia mediante la reducción de colusión en los procedimientos de licitación en Latinoamérica, V Reunión Anual del Foro Latinoamericano de la Competencia (Puebla, México, 20 de septiembre de 2007). Disponible en: www.oedc.org, http://www.oecd.org/officialdocuments/ publicdisplaydocumentpdf/?cote $=\mathrm{DAF} / \mathrm{COMP} / \mathrm{LACF}(2007) 2 \&$ docLanguage $=$ En

26 Según las cifras proporcionadas por el portal de contratación del Estado, a septiembre de 2015 se realizaron 432.203 procesos de contratación directa correspondientes a $\$ 482.753 .773 .783 .968$, mientras que por el mecanismo de licitación pública se adelantaron 10.303 procesos que correspondieron a $\$ 24.923 .659 .251 .861$. Como se puede deducir de estas cifras, aun cuando la mayoría de los procesos contractuales se desarrolla por el mecanismo de contratación directa, la licitación pública sin duda sigue siendo el procedimiento por el cual se adelantan las contrataciones más significativas. http://www.colombiacompra.gov.co/sites/default/files/ reportes_mensuales/10-octubre-2015.pdf

27 Se afecta en la medida en que un proceso licitatorio manipulado conducirá a uno de dos escenarios: 1) que se seleccione al oferente que presente una oferta con el precio más bajo, respecto del cual, durante el desarrollo del contrato se solicitará un reajuste; 2) que se seleccione una propuesta con un precio significativamente más alto de aquel que se habría podido obtener de 
entre competidores, sino de un acuerdo en el que priman los intereses particulares sobre los generales ${ }^{28}$. Estas conductas hacen que pierda el Estado, que pierdan los contribuyentes, que pierda la transparencia del proceso y que pierda el mercado; en resumidas cuentas, ganan unos pocos en perjuicio de $\operatorname{todos}^{29}$.

En este escenario, resultan de la mayor importancia las medidas que el Estado pueda tomar para evitar la conformación de estos acuerdos nocivos y con ello no nos referimos solamente a las sanciones penales o administrativas que se pueden implementar respecto a aquellas conductas que ya han tenido ocurrencia, sino también a aquellas que pueden adoptarse de manera previa a su realización; esto es, desde la propia etapa de planeación o de elaboración de la oferta o de los pliegos, la Administración puede implementar medidas que garanticen que todos los competidores puedan acceder al proceso contractual para ofrecer sus bienes y servicios, en un escenario de igualdad, transparencia y sin barreras injustificadas.

haberse dado una verdadera competencia. En todo caso, la consecuencia es que se afectarán el erario y los intereses de los demás proponentes.

28 "En el caso de la colusión en proceso de selección la afectación de intereses colectivos es doble. Se vulnera tanto el interés colectivo de la libre competencia como el relacionado con la protección del patrimonio público en la medida en que se disminuyen las posibilidades de asignación eficiente de recursos por parte de la respectiva entidad estatal". Superintendencia de Industria y Comercio, Resolución 1055 de 2009.

29 En este punto resultan interesantes las conclusiones del Foro Latinoamericano de Competencia, auspiciado por la OCDE, que sobre los efectos de la colusión y la corrupción en la contratación pública considera: "La distorsión del proceso de contratación mediante la colusión o la corrupción suele tener un efecto particularmente perjudicial en el contexto del sector público. Una contratación pública eficaz determina la calidad de la infraestructura y los servicios públicos e incide en la variedad y la penetración de la infraestructura y los servicios que un Estado puede proporcionar a sus ciudadanos. La contratación pública es una cuestión de máxima importancia para el desarrollo económico de un país: (i) los bienes y servicios objeto de contratación pública suelen afectar a una gran parte de la población; (ii) la contratación pública atañe a menudo a la infraestructura física o a la salud pública, lo que respalda otras formas de actividad económica; (iii) repercute en la competitividad internacional; (iv) puede tener consecuencias en el clima de inversión; (v) la distorsión de la contratación pública suele hacer pesar los efectos más perjudiciales sobre las personas más desaventajadas de la sociedad, que dependen en mayor medida de los servicios y la infraestructura públicos; y (vi) la contratación pública suele tener por objeto 'bienes públicos', por lo que los mecanismos del mercado privado no pueden responder a las insuficiencias gubernamentales". Organización para la Cooperación y el Desarrollo Económicos, OCDE, Foro Latinoamericano de Competencia, Sesión III, Mejorando la eficacia en las licitaciones públicas: combatiendo la colusión y la corrupción, Documento Base, DAF/COMP/LACF(2012)7, 18 al 19 de septiembre de 2012, República Dominicana, 6. Disponible en: http://www.oecd.org/officialdocuments/publicdis playdocumentpdf/?cote $=\mathrm{DAF} / \mathrm{COMP} / \mathrm{LACF}(2012) 2 \&$ docLanguage $=\mathrm{Es}$ 


\section{La COLUSIÓN EN COLOMBIA. DEFINICIÓN Y ÁMBITO DE APLICACIÓN}

En Colombia, la colusión o acuerdo entre competidores está tipificada como una conducta contraria a la libre competencia en el numeral 9 del artículo 47 del Decreto 2153 de 1992, que al respecto ha consagrado: "los que tengan por objeto la colusión en las licitaciones o concursos ${ }^{30} \mathrm{o}$ los que tengan como efecto la distribución de adjudicaciones de contratos, distribución de concursos o fijación de términos de las propuestas".

Así las cosas, para hablar de un acuerdo restrictivo de la competencia bajo la modalidad de colusión, se requiere el cumplimiento de los siguientes supuestos que definen la tipicidad de la conducta:

\section{A. Un acuerdo entre dos o más sujetos}

Respecto al primer requisito, debemos indicar que nuestra legislación entiende por acuerdo todo contrato, convenio, concertación, práctica concertada o conscientemente paralela entre dos o más empresas $^{31}$. Entonces, a la par de la bilateralidad o multilateralidad se exige una actuación conjunta o mancomunada, esto es, la voluntad o consenso de las partes de llevar a cabo una conducta restrictiva de la competencia, con independencia de que esta conducta concrete sus efectos. En el caso de la colusión, será colusorio el acuerdo entre competidores "cuando, con la intención de obtener un resultado favorable en uno o varios procesos contractuales, se convenga con anticipación las condiciones en que van a actuar cada uno de ellos con el objeto de abstenerse de competir o de excluir a otros competidores potenciales" 32 .

30 El artículo 32 de la Ley 1150 de 2007 eliminó las expresiones "concurso" y "términos de referencia".

31 Art. 45 del Decreto 2153 de 1992. Sobre este particular, las resoluciones de la Superintendencia de Industria y Comercio, 19924 de 2003, 21822 de 2004, 55463 de 2011, 49454 de 2011, 64400 de 2011, 24646 de 2011, entre otras. Ahora, ya refiriéndonos concretamente al acuerdo y su interrelación con la norma citada, se debe tener en cuenta que este: “(...) puede tener lugar cuando se verifica la ocurrencia de cualquiera de las modalidades enunciadas en la norma referida, las cuales suponen un comportamiento consecuente de agrupación de objetivos y finalidades en una actuación coordinada". Superintendencia de Industria y Comercio, Resolución 1055 de 2009, 11.

32 Superintendencia de Industria y Comercio, Resolución 1055 de 2009, sobre la definición de colusión. Igualmente, ver las resoluciones 44008 de 2010, 55463 de 2011, 49454 de 2011, 64400 de 2011 y 24646 de 2011, entre otras. 
Ahora bien, en cuanto a la calidad de los sujetos que hacen parte del acuerdo, la definición que realiza el artículo 45 del Decreto 2153 de 1992 parece restringirla a que el mismo se celebre entre dos o más empresas. Sin embargo, en nuestra opinión esta posición puede ser discutible, en la medida en que a partir de la introducción del artículo 2 de la Ley 1340 de 2009, se habría extendido el ámbito subjetivo de aplicación de las normas sobre protección de la competencia, a "(...) todo aquel que desarrolle una actividad económica o afecte o pueda afectar ese desarrollo independientemente de su forma o naturaleza jurídica y en relación con las conductas que tengan o puedan tener efectos total o parcialmente en los mercados nacionales, cualquiera que sea la actividad o sector económico". De esta manera, un acuerdo - y más concretamente uno de carácter colusorio - podría ser llevado a cabo por dos o más empresas, 


\section{por personas jurídicas, por otras formas asociativas, por personas naturales ${ }^{33} \mathrm{e}$ incluso por servidores públicos ${ }^{34}$.}

33 La Superintendencia se pronunció específicamente sobre este tema en el caso IDIPRON, Instituto Distrital para la Protección de la Niñez y la Juventud, y de manera expresa indicó respecto a la posibilidad de que las personas naturales lleven a cabo acuerdos restrictivos de la competencia, lo siguiente: "Así, de seguir la interpretación del recurrente según la cual no le es aplicable el artículo 25 de la Ley 1340 de 2009 (numeral 15 del artículo 4 del Decreto 2153 de 1992), se llegaría a la conclusión de que no es posible sancionar una persona natural que actúa como agente del mercado, en calidad de comerciante, y no como persona jurídica, por la comisión de conductas anticompetitivas como carteles o abusos de posición dominante, en la medida en que la sanción a persona natural del artículo 26 de la ley 1340 de 2009 solamente opera cuando se ha sancionado la persona jurídica a la cual pertenece la persona natural, y cuando esta última ha tolerado, ejecutado, colaborado, etc. en la conducta cometida por la persona jurídica o empresa que actuó como agente del mercado.

Dicha interpretación sería absurda y contraria al espíritu de la norma, en la medida en que existen múltiples comerciantes que en calidad de personas naturales manejan empresas, como por ejemplo, Arturo Calle, que no podrían bajo ningún punto de vista quedar fuera del régimen sancionatorio de libre competencia, y que son incluso más grandes que muchas personas jurídicas.

Ahora bien, si a las personas naturales que actúan como agentes del mercado (y no como agentes, representantes o miembros de una persona jurídica), no les es aplicable el artículo 26 (numeral 16 del artículo 4 del Decreto 2153), la pregunta es qué norma les es aplicable conforme al régimen de competencia colombiano, y la respuesta no es otra que el propio artículo 25 . Cuando se analiza el texto del artículo 25, se puede ver cómo el artículo (...) Nótese que el artículo, que es el vigente para estos efectos, habla de infractor, sin hacer distinciones entre personas naturales o jurídicas. Es decir, la norma abarca a cualquier persona que actúe en calidad de infractor, como agente de mercado, de las normas de competencia, independientemente de su naturaleza jurídica.

(...) Así, si a una persona natural le aplica el régimen de competencia en los mismos términos que a una persona jurídica, según el artículo 2, es claro que cuando el artículo 25 habla de "infractor" incluye a cualquier agente del mercado que actúe como tal, independientemente de su naturaleza jurídica. Esto, por supuesto, implica que las personas naturales, cuando actúan como agentes del mercado, son merecedoras del régimen sancionatorio establecido en el artículo 25. (...) Cuando la persona natural actúa como infractora directamente, le aplica entonces el artículo 25 de la ley 1340 de 2009, que realmente es el numeral 15 del artículo 4 del Decreto 2153 de 1992.

Desconocer que la persona natural puede ser infractora, y que solo se le puede sancionar cuando hay de por medio una persona jurídica, dejaría sin piso el artículo 2 de la Ley 1340 de 2009 (...)" (negrita por fuera del texto). Resolución 66698 de 2013, por la cual se resuelve un recurso de reposición.

En ese mismo sentido nos permitimos citar el caso INPEC, Instituto Nacional Penitenciario y Carcelario, en el cual se sancionó a tres personas naturales por la presunta comisión de un acuerdo colusorio dentro de la Licitación Pública 001 de 2011. En este caso, la Superintendencia ya no restringió la noción de acuerdo al celebrado entre dos o más empresas sino al acuerdo entre dos o más sujetos, al indicar que: "Cabe resaltar que cualquier forma de acuerdo entre dos o más sujetos (personas naturales o jurídicas) que busque alterar las condiciones mediante las cuales se desarrollan los procesos de selección con el Estado, contraviene no solo las normas de competencia, sino también las normas que regulan la contratación estatal". Superintendencia de Industria y Comercio, Resolución 40901 de 2012, 12.

34 En este punto, resulta necesario indicar que con el Proyecto de ley 038 de 2015 que actualmente cursa en el Congreso y "por el cual se introducen modificaciones al régimen de protección de la competencia, a las funciones de la Superintendencia de Industria y Comercio, y se dictan otras disposiciones", se excluiría esta posibilidad, en la medida en que artículo 5 del proyecto que modifica el numeral 15 del artículo 4 del Decreto 2153 de 1992, realiza una cualificación del sujeto activo de la conducta al determinar que la Superintendencia de Industria y Comercio 
En contra de lo anterior, resalta la opinión de Felipe SerranoPinilla, que de manera enfática señala: “(...) la norma que prohíbe la colusión en licitaciones sanciona únicamente los acuerdos de no competencia realizados entre empresa, y no los acuerdos entre funcionarios públicos y empresas privadas para determinar el destino de una licitación. Por esta razón, la herramienta utilizada por la Superintendencia de Industria y Comercio, SIC, para preservar la competencia en la contratación pública es insuficiente para atacar pactos de no competencia que involucran la intervención de un funcionario público y una empresa. La agencia de competencia colombiana, tradicionalmente, ha concentrado sus esfuerzos en combatir exclusivamente los acuerdos entre competidores y no los acuerdos entre empresas y funcionarios que también afectan la competencia, lo cual, desde una perspectiva de política de competencia, puede resultar subóptimo" 35 .

En cuanto a la voluntad de los agentes, esta ha de estar encaminada a la concertación de formas de manipulación de los procesos de selección, para alcanzar la adjudicación de un contrato al margen del juego competitivo. Aquí "las maniobras fraudulentas pueden provenir del acuerdo de las partes (colusión) para perjudicar a terceros, o de una de las partes para perjudicar a la otra" ${ }^{\text {"36. }}$.

podrá imponer sanciones pecuniarias a los "agentes del mercado", sean personas naturales o jurídicas, por la violación de cualquiera de las disposiciones sobre protección de la competencia; con lo cual quedaría en duda la aplicación de estas normas a servidores públicos, pues no encuadrarían en estas categorías. Así mismo, esta norma resulta un contrasentido, teniendo en cuenta que el proyecto de ley no contempla la modificación del artículo 2 de la Ley 1340 de 2009 y en esa medida estaríamos ante dos normas contradictorias, que establecerían ámbitos subjetivos de aplicación distintos. Colombia, Proyecto de ley 038 de 2015, por el cual se introducen modificaciones al régimen de protección de la competencia, a las funciones de la Superintendencia de Industria y Comercio, y se dictan otras disposiciones. Disponible en: http://www.sic.gov.co/drupal/sites/default/files/files/PROYECTO_DE_LEY\%20_DE\%20_ COMPETENCIA.pdf

35 Felipe Serrano-Pinilla, El derecho de la competencia como mecanismo para garantizar rivalidad en las licitaciones públicas e impulsar el crecimiento económico, 9 International Law, Revista Colombiana de Derecho Internacional, 19, 147-182, 157 (julio-diciembre de 2011). Disponible en: http://revistas.javeriana.edu.co/index.php/internationallaw/article/view/13737/0

36 Corte Suprema de Justicia, Sala de Casación Civil, sentencia de revisión 007, Proceso 3348, magistrado ponente Nicolás Bechara-Simancas, 26 de enero de 1995. 


\title{
B. Que el acuerdo tenga por objeto la colusión en licitaciones o concursos o como efecto la distribución de adjudicaciones de contratos, distribución de concursos o fijación de los términos de las propuestas
}

\author{
En el caso colombiano, compartimos lo señalado por una parte de \\ la doctrina, en el sentido de que frente a la definición de prácticas \\ restrictivas de la competencia por objeto y como efecto, no se han \\ sentado las pautas ni legales ni jurisprudenciales para su concre- \\ ción ${ }^{37}$.
}

37 Sobre este particular, encontramos la opinión de Aníbal Rafael ZÁrate-Pérez: "Las correcciones que el fallo del Consejo de Estado aporta en el presente caso, a pesar de constituir un esfuerzo de análisis de cuestiones de fondo ligadas a la aplicación de las normas de libre competencia, dejan todavía entrever cómo hasta ahora el alcance del control del juez se concentra esencialmente en el respeto por parte de la autoridad de la competencia de las formas y de las garantías procesales de los operadores económicos en sus actuaciones. Esta es la razón por la cual el Consejo de Estado aparece fundamentando en particular desde el campo de la responsabilidad objetiva, sin entrar a determinar aquello que debe entenderse 'por objeto' o 'como efecto', esto es, sin abarcar consideraciones o desarrollos desde el principio de la eficiencia económica". Aníbal Rafael Zárate-Pérez, Análisis económico por el juez de lo contencioso administrativo. Prácticas restrictivas de la competencia. Acuerdos de fijación de precios. Consejo de Estado, Sala de lo Contencioso Administrativo, Sección Primera, sentencia del 28 de enero del 2010, expediente $n^{\circ}$ 25000-23-24-000-2001-00364-01, en Los grandes fallos de la jurisprudencia administrativa colombiana, 410-418, 417-418 (ANDRÉs Fernando Ospina-Garzón, ed., Universidad Externado de Colombia, Bogotá, 2013). En este mismo sentido, Rafael TAMAYo-Álvarez señala: "El problema está en que el Consejo de Estado omitió definir el sentido de las expresiones por objeto o como efecto, ni estableció criterios para poder distinguir un concepto del otro. Fue esta imprecisión la que condujo a que el Consejo fundamentara su decisión en consideraciones que no guardan relación con el principio de eficiencia económica. Por el contrario, su análisis del caso conduce al campo de la responsabilidad objetiva, debido a que para el Consejo de Estado las expresiones por objeto u efecto guardan relación con el hecho de poder identificar el componente subjetivo que motivó a las partes a coordinar sus precios; mas no con la función de analizar la manera como el acuerdo incide sobre el buen funcionamiento del mercado y el interés de los consumidores". RaFAel TAMAYo-Álvarez, Fundamentos económicos para la aplicación de las normas de libre competencia y el caso ANDEVIP y la existencia de prácticas restrictivas absolutas en Colombia, 6 Revista del Derecho de la Competencia, 6, 145-172, 167 (Bogotá, enero-diciembre 2010). Disponible: www.javeriana.edu.co, https://centrocedec.files.wordpress.com/2010/06/4tamayo-alvarez.pdf. Estamos totalmente de acuerdo con la opinión de estos doctrinantes, pues consideramos totalmente criticable el hecho de que ni la legislación ni la jurisprudencia ni mucho menos la doctrina de la Superintendencia de Industria y Comercio, SIC, han sido claras en determinar si en Colombia se aplica la regla de la razón o la regla per se, ni tampoco se ha dado una definición clara y precisa de lo que debe entenderse por acuerdos por objeto o como efecto. Así mismo, resulta reprochable que si bien la SIC al momento de analizar la conducta establece que un acuerdo colusorio puede tener por objeto o como efecto la colusión, al adecuar la conducta no siempre determina si la misma fue cometida por objeto o como efecto, y se limita simplemente a decir que la misma resulta lesiva tanto para el mercado y el interés general, como para la contratación estatal, lo cual —en nuestro criterio — además de atentar contra los principios que deben regir el derecho administrativo sancionador, contrasta con la 
Por lo anterior, se puede sostener que en el panorama jurídico colombiano frente a la aplicación de las normas del Decreto 2153 de 1992 relativas a las conductas restrictivas de la competencia, no se puede predicar que las mismas atiendan a una lógica de la razón "por objeto" y "como efecto" equivalente al sistema comunitario europeo $^{38} \mathrm{y}$, más allá, tampoco podría aseverarse que haya prácticas restrictivas absolutas de la competencia ${ }^{39}$ como en el sistema estadounidense ${ }^{40}$.

Sin embargo, no puede dejar de observarse que en Colombia el análisis de una práctica comercial restrictiva parece centrarse en si la misma generó efectos anticompetitivos, pero no en si pueden

posición del Consejo de Estado, en el sentido de que para sancionar un acuerdo anticompetitivo resulta indispensable establecer si el mismo tuvo por objeto o como efecto restringir la competencia. Consejo de Estado, Sala de lo Contencioso Administrativo, Sección Primera, Proceso 00364, Caso ANDEVIP, Sentencia del 18 de enero de 2010, consejera ponente María Claudia Rojas-Lasso.

38 En el Derecho Europeo, existe la distinción entre prácticas restrictivas de la competencia por objeto y como efecto, siendo las primeras de mayor gravedad que las segundas, pues cuando un acuerdo tiene por objeto restringir la competencia no se requiere demostrar que se dio un efecto restrictivo sobre la misma. Unión Europea, Reglamento (CE) 1/2003 del Consejo, de 16 de diciembre de 2002, relativo a la aplicación de las normas sobre competencia previstas en los artículos 81 y 82 del Tratado. Disponible en: http://eur-lex.europa.eu/legal-content/ ES/TXT/?uri=URISERV:126092. Unión Europea, Tratado de Funcionamiento de la Unión Europea, TFUE, C83 Diario Oficial de la Unión Europea, 30 de marzo de 2010. Disponible en: http://www.boe.es/doue/2010/083/Z00047-00199.pdf

39 No obstante nuestra posición, debemos señalar que en criterio de la Superintendencia de Industria y Comercio, la regla per se sí es aplicable en Colombia, para lo cual trae a colación una serie de reglas de interpretación muy cercanas a la normatividad estadounidense, al decir que: "Siendo así, tenemos que la llamada la regla per-se no solo es aceptada y reconocida por nuestra legislación sino que es de forzosa aplicación al momento de analizar la infracción al número 1 del artículo 47 del decreto 2153 de 1992, toda vez que se trata de un acuerdo específicamente tipificado en nuestra legislación". Superintendencia de Industria y Comercio, Resolución 14540 de 2002, 19.

40 En el Derecho Antitrust de Estados Unidos, las prácticas restrictivas de la competencia relativas se refieren a aquellas que consecuencialmente implican el ejercicio de un análisis bajo la regla de la razón que permita establecer la real y sustancial afectación al mercado - es decir, que dando aplicación a la teoría de la eficiencia en el mercado, se estudia la conducta que en principio se muestra anticompetitiva para analizar si esta efectivamente lo afecta de forma sustancial o si, por el contrario, representa una ventaja para el mismo, conocida como eficiencia pro-competitiva-; por su parte, las prácticas absolutas de la competencia o practicas per se - que generan en nuestra opinión una presunción de derecho-afectan el mercado de forma inmanente a su existencia y merecen el reproche y la sanción del Estado, sin que sea necesario analizar si efectivamente se afectó o no la competencia, por lo tanto una vez imputada la conducta, la única manera en que podrá exonerarse el investigado será: o probando la no ocurrencia de la conducta o su no participación en la misma. Estados Unidos, Consolidated Antitrust Laws from the United States Code, 15 US Code $§ \S 1-7$ (Sherman Act); 15 US Code $\S \S 12-27$ and 29 US Code $\$ \S 52-53$ (Clayton Act); 15 US Code $\S \S 41-58$ (The Federal Trade Commission Act); 15 US Code $\S 13$ (Robinson-Patman Act). Disponible en: http://www.wipo.int/wipolex/en/details.jsp?id=5408 
atribuírsele posibles eficiencias procompetitivas ${ }^{41}$. Concretamente, en el caso de las resoluciones emitidas por la SIC, en las que se ha analizado la posible ocurrencia de un acuerdo colusorio, el examen se ha centrado en la existencia de un acuerdo que haya aumentado las posibilidades de obtener la adjudicación del contrato para los agentes coludidos y que, a su vez, haya disminuido las posibilidades de los demás proponentes ${ }^{42}$ no integrantes del acuerdo; no obstante, no se indaga sobre si el mismo pudo proporcionar efectos positivos en el mercado, verbigracia, que se le haya adjudicado al proponente con mayor experiencia, o al que ofreció un mejor precio, o al que presentó realmente la oferta más favorable.

En efecto, la práctica muestra que al momento de condenar, por lo menos un acuerdo colusorio, la Superintendencia no toma en cuenta los factores antes mencionados. Incluso, cuando analiza la conducta desde el punto de vista del objeto, le ha sido suficiente la existencia de un acuerdo tendiente a la manipulación de un proceso de selección para que la conducta sea sancionada ${ }^{43}$, con independen-

41 En el caso europeo, frente a ambas conductas habrá que realizar un análisis de valoración, relativo a determinar la afectación de la competencia para efectos de su sanción; así, es posible entonces, la aplicación de la "exención de eficiencia", para efectos de la imposición de la sanción. En ese sentido, en el sistema europeo, esta exención se da "Cuando los efectos favorables a la competencia de un acuerdo superan a los restrictivos, el acuerdo es en definitiva beneficioso para la competencia y compatible con los objetivos de la normativa comunitaria en esta materia. Los efectos netos de tales acuerdos consisten en fomentar la propia esencia del proceso competitivo, a saber, obtener clientes mediante la oferta de mejores productos o precios más ventajosos que los que ofrecen los competidores. Este marco analítico se refleja en los apartados 1 y 3 del artículo 81 . En este último se reconoce expresamente que los acuerdos restrictivos pueden comportar beneficios económicos objetivos que compensen los efectos negativos de la restricción de la competencia”. Comisión Europea, Comunicación de la Comisión. Directrices relativas a la aplicación del apartado 3 del artículo 81 del Tratado, C 101 Diario Oficial de la Unión Europea, 97-118, 27 de abril de 2004. Disponible en: http://eur-lex. europa.eu/LexUriServ/LexUriServ.do?uri=CELEX:52004XC0427(07):ES:HTML

En el caso colombiano, la excepción de eficiencia ha sido expresamente consagrada — tanto por el Decreto 2153 de 1992 como por la Ley 1340 de 2009- para las integraciones empresariales, hoy la norma está consagrada en el artículo 12 de la Ley 1340 de 2009.

42 Como sustento de esta afirmación, traemos a colación lo dicho por la SIC en el caso INTERSYSTEM, en el cual señaló expresamente: "La labor de investigación adelantada estuvo orientada a determinar si la persona jurídica y las personas naturales investigadas, previo acuerdo, ejecutaron conductas que hubiesen tenido como objeto lo siguiente: a. Aumentar la posibilidad de obtener la adjudicación de los contratos para sistematización de notas mediante la inscripción en las convocatorias y, en caso de ser elegido uno de ellos como hábil para proponer, los demás investigados, también elegidos, se abstenían de presentar la respectiva propuesta. b. Disminuir la posibilidad de los participantes inscritos en los procesos de contratación, de ser seleccionados para presentar sus propuestas". Superintendencia de Industria y Comercio, Resolución 1055 de 2009, 12.

43 Claro, tampoco estamos afirmando que no se hayan presentado otros elementos probatorios para sustentar la condena, lo que afirmamos es que la Superintendencia sanciona la sola 
cia de la intención o justificación de las partes ${ }^{44}$, de la producción o no de un daño o perjuicio ${ }^{45}$, de los efectos de la conducta sobre el bienestar de los consumidores, de la eficiencia del mercado ${ }^{46}$, o de la existencia de ventajas procompetitivas. En ese sentido, la forma de valorar esta conducta se acerca más a las denominadas reglas per se que a las reglas de la razón.

Como evidencia de lo anterior, hacemos notar que en Colombia solamente ha sido posible la exoneración de la conducta en casos de colusión - esto es el cierre de la investigación - porque no se han encontrado pruebas suficientes para sancionar ${ }^{47}$ o porque no se han cumplido los supuestos de la norma ${ }^{48}$, mas no por una comparación

existencia del acuerdo sin analizar otra clase de elementos que pueden subyacer al mismo.

44 Por ejemplo, ver resoluciones 69716 de 2009, 30 de 2012 y 40875 de 2013, en las cuales la Superintendencia de Industria y Comercio se apartó del criterio de la intencionalidad para sustentar la condena a los investigados.

45 Esta posición se evidencia en el caso IDIPRON, en el cual la SIC se pronunció respecto a los argumentos esbozados por los investigados en el sentido de que la conducta no produjo daño alguno. En efecto, en este caso, la Superintendencia expresó: "Es así como al respecto, esta Entidad en diversas ocasiones se ha pronunciado sobre las conductas anticompetitivas por objeto. En el caso ACEMI [Asociación Colombiana de Empresas de Medicina Integral] (2011), la SIC sostuvo, que en los casos de conductas anticompetitivas por objeto, no se requiere de la demostración de sus efectos. Por tal razón, es suficiente contar con evidencia que permita mostrar la realización de la conducta anticompetitiva y que el objeto de la misma sea el de restringir la competencia o el de determinar de manera ficticia las condiciones del mercado para considerarla como reprochable. (...) Ello es así por cuanto la conducta colusoria es sancionable no solamente cuando produce efectos, sino también cuando se realiza con el objeto de coludir". Resolución 53914 de 2013, 69. Así mismo, por ejemplo en el denominado caso INTERSYSTEM, la SIC acepta que si bien no en todos los casos el acuerdo conllevó la adjudicación del contrato, la conducta debía ser sancionada. Superintendencia de Industria y Comercio, Resolución 1055 de 2009, 18.

46 No obstante, es uno de los criterios que dice analizar para determinar si la conducta es significativa, como veremos más adelante.

47 Esto se evidenció por ejemplo en la Resolución 47481 de 2010, por la cual se cierra una investigación en contra de varias empresas de telecomunicaciones en un proceso de contratación. En este caso, la Superintendencia encontró que si bien era posible manipular el sistema de puntuación de la licitación, para que el acuerdo colusorio fuera sostenible, se requería que las partes pudieran monitorearse mutuamente al momento de presentar sus ofertas, de lo cual la Superintendencia no encontró evidencias. En ese orden de ideas, la entidad ordenó el cierre de la investigación pues en su criterio había otras explicaciones plausibles para las asimetrías en las estructuras de costos de los participantes, de tal manera que la evidencia que encontró en el expediente no sustentaba de manera inequívoca la presencia de acuerdos colusorios entre las investigadas. Superintendencia de Industria y Comercio, Resolución 47481 de 2010.

48 En efecto, en la Resolución 17499 de 2008, mediante la cual se cerró una investigación por posible colusión, uno de los argumentos que esbozó la entidad es que: "No obstante, las pruebas recaudadas en el transcurso de la investigación no permiten demostrar que la participación de los investigados en los aludidos concursos haya estado precedida de la realización de un acuerdo entre ellos". Superintendencia de Industria y Comercio, Resolución 17499 de 2008, 3. Sobre este particular, ver también las resoluciones 19924 de 2003, 21596 de 2004 y 47481 de 2010 , entre otras. 
entre los efectos negativos y los beneficios o bondades que el acuerdo haya podido traer para la eficiencia del mercado.

Lo anterior resulta criticable - en nuestra opinión - en la medida en que entendiendo que la norma distingue entre los acuerdos que tengan por objeto la colusión en licitaciones o concursos o, como efecto la distribución de adjudicaciones de contratos, distribución de concursos o fijación de los términos de las propuestas, actualmente en nuestro derecho de la competencia no es posible hablar de un régimen de responsabilidad objetiva ${ }^{49}$ que parta de la concepción de que los acuerdos colusorios son conductas restrictivas de la competencia de carácter absoluto ${ }^{50}$, en razón de lo cual, consideramos que la posición de la autoridad de competencia tendiente a condenar

49 Al respecto, en el caso ANDEVIP [Asociación Nacional de Entidades de Seguridad Privada], el Consejo de Estado sostuvo: "Visto lo anterior, observa la Sala que la parte demandante incurre en error al formular el cargo de violación de los actos administrativos demandados relativo a que el tipo de responsabilidad atribuible a las empresas infractoras en este tipo de situaciones no es objetiva, sino subjetiva, bajo el entendido de que no basta solo con la existencia del acuerdo. Cierto es, como lo dicen los demandantes, que no basta con la sola demostración de la existencia del acuerdo de precios, sin embargo, no lo es tanto que además sea menester probar la intención que tenían las sociedades infractoras al momento de su celebración para que proceda la imposición de las sanciones de rigor. Lo anterior tiene sentido si se observa que el tenor literal del artículo 47 del Decreto 2153 de 1992, contentivo de las conductas que se consideran prácticas comerciales restrictivas, señala claramente que además de la existencia del pacto de precios - sea cual sea su naturaleza - es indispensable que tenga por objeto o efecto la fijación directa o indirecta de precios. Es por ello, que no interesa la intención que la parte demandante dijo tener al momento en que celebró el acuerdo de precios censurado por la Superintendencia de Industria y Comercio - y que dicho sea de paso, no demostró-, puesto que lo que importaba a efectos de la procedencia de las sanciones correspondientes, era, además de la existencia del acuerdo, como ya se dijo, que este tuviera por objeto o por efecto la fijación indirecta o directa de precios". Y continúa el Consejo de Estado para descartar la aplicación de una responsabilidad objetiva diciendo: “(...) Lo dicho además descarta de plano la teoría del actor según el cual el tipo de responsabilidad en el que la demandada sustentó la imposición de la multa es objetiva, comoquiera que se aparecía un claro componente subjetivo en el tenor literal numeral 1 del artículo 47 del Decreto 2153 de 1992, al señalar que son prácticas comerciales restrictivas, aquellas que tengan por 'objeto o efecto, la fijación directa o indirecta de precios (...)" (las negritas son nuestras). Consejo de Estado, Sala de lo Contencioso Administrativo, Sección Primera, Proceso 00364, Caso ANDEVIP, Sentencia del 18 de enero de 2010, consejera ponente María Claudia Rojas-Lasso. Si bien el Consejo de Estado realiza estas consideraciones a propósito del acuerdo de precios, ello no es óbice para que sus consideraciones sobre responsabilidad objetiva y los acuerdos por objeto o como efecto, se apliquen al caso que nos ocupa. La Corte Constitucional de Colombia ya se había pronunciado sobre la aplicación de la responsabilidad objetiva: "En consecuencia, carece de respaldo constitucional la imposición de sanciones administrativas de plano con fundamento en la comprobación objetiva de una conducta ilegal, en razón del desconocimiento que ello implica de los principios de contradicción y de presunción de inocencia, los cuales hacen parte del núcleo esencial del derecho al debido proceso". Corte Constitucional, Sentencia T-145-93, 21 de abril de 1993, magistrado ponente Eduardo Cifuentes-Muñoz. Disponible en: http://www.corteconstitucional.gov.co/ relatoria/1993/t-145-93.htm

50 Con la salvedad ya realizada respecto a la aplicabilidad de la regla per se en derecho colombiano, según el criterio de la SIC. 
la sola existencia del acuerdo, es contraria a esta prohibición. Por lo tanto, en nuestro parecer, la autoridad al momento de adecuar la conducta colusoria debería tomar en consideración tanto los efectos de la conducta sobre la libertad de competencia, el bienestar de los consumidores, la eficiencia económica, la intención de las partes, la existencia o no de ventajas procompetitivas derivadas del acuerdo colusorio, como la producción o no de un daño o perjuicio. Si bien no para exonerar de sanción la conducta, sí al menos para considerar una posible dosificación de la misma ${ }^{51}$.

Respecto a lo anterior, en todo caso debe advertirse que aun cuando la postura que ha asumido el Consejo de Estado es clara respecto a que la responsabilidad atribuible a quienes celebran acuerdos anticompetitivos no es objetiva sino subjetiva ${ }^{52}$, la Superintendencia de Industria y Comercio parece renuente a la aplicación de esta postura, pues lo que se evidencia en la práctica es que si bien la autoridad de competencia ha llegado a tomar en cuenta elementos subjetivos al momento de sancionar, lo ha hecho para dosificar la sanción ${ }^{53}$ - ya

51 Si bien la Ley 1340 de 2009, en sus artículos 25 y 26, introduce una serie de criterios para la graduación de la multa, tanto para personas naturales como jurídicas, estos guardan relación con el impacto de la conducta, la dimensión del mercado afectado, el beneficio obtenido, el grado de participación, la conducta procesal de los investigados, la cuota de mercado y el patrimonio del infractor; pero no se refieren a la posibilidad de tomar en consideración los factores que hemos mencionado.

52 Esto tampoco quiere decir que estemos afirmando que la Superintendencia deba demostrar la mala fe de los investigados para poder sancionar su conducta, pues como también dice el Consejo de Estado en la sentencia en cita: "La calificación de buena o mala fe para el obrar de alguien es un calificativo moral. La libre competencia es un bien jurídicamente tutelado y por ello obrar en su contra es un comportamiento malo y censurable. Para esta Entidad quien concientemente ( $\mathrm{sic}$ ) desarrolla un acuerdo de precios, obra de mala fe. (...) [Sin embargo] las disposiciones sobre prácticas restrictivas no tienen como elemento ' $l a$ mala fe'. Precisamente en la redacción del número 1 del artículo 47 del Decreto 2153 de 1992, se proscriben los acuerdos 'que tengan por objeto o tengan como efecto la fijación directa o indirecta de precios'. Es decir, no se requiere acreditar una intencionalidad adicional en la conducta desplegada por los agentes económicos, basta simplemente demostrar un objeto o la realización efectiva de la fijación de precios, efecto, independiente del aspecto volitivo, que se hubiese podido tener. Así, y en cuanto hace a la supuesta falla de intención de los sancionados de causar una indebida limitación de la competencia, que en criterio del apoderado harían imposible la tipificación de la conducta, debemos señalar que de acuerdo con lo expuesto anteriormente, resulta irrelevante para el caso concreto el propósito que precedió al convenio celebrado". Consejo de Estado, Sala de lo Contencioso Administrativo, Sección Primera, Proceso 00364, Caso ANDEVIP, Sentencia del 18 de enero de 2010, consejera ponente María Claudia RojasLasso.

53 Por ejemplo, en el caso Cárceles, se sancionó a una sociedad extranjera por el actuar de su mandatario; si bien la sanción que se impuso fue más laxa que a los demás involucrados, la SIC atendió a criterios de falta de diligencia para imputar responsabilidad a la empresa, aun cuando no se comprobó que la misma haya actuado de manera directa en el acuerdo. Superintendencia de Industria y Comercio, Resolución 53991 de 2012, 112 y 132. 
sea para aumentarla o disminuirla - mas no para exonerar de responsabilidad; de manera que si la conducta investigada se ajusta a los supuestos establecidos en la norma, la misma será sancionada ${ }^{54}$, con independencia de los móviles o intereses que hayan determinado la estructuración del acuerdo - esto tanto en acuerdos de precios como en prácticas colusorias -55 . Lo anterior no ocurriría de encontrarnos en un verdadero escenario de responsabilidad subjetiva, pues la ausencia de dolo o de culpa bastaría para lograr la exoneración de responsabilidad, lo cual, repetimos, no ocurre en el caso colombiano. Por lo tanto, la aplicabilidad de una responsabilidad subjetiva en materia de acuerdos restrictivos de la competencia en el derecho colombiano, no resulta del todo clara ni mucho menos pacífica ${ }^{56}$.

54 "De esta manera el Consejo no le dio la razón a la SIC que argumentó ante el Tribunal Administrativo de Cundinamarca que el sistema de imputación que debía aplicarse a los [sic] era de naturaleza objetiva. Sin embargo, se reitera que en la práctica la interpretación del Consejo de Estado sobre el sistema de imputación aplicable a este tipo de casos no varía la manera como la SIC evalúa la legalidad de la conducta de las empresas. En efecto, al motivar sus decisiones la SIC confronta las conductas de las empresas acreditadas en el proceso frente a los supuestos fácticos descritos por las conductas definidas como 'anticompetitivas' por el Decreto 2153 de 1992. Cuando una conducta se adecua a todos los supuestos de hecho de la conducta tipificada según lo acreditado en el proceso serán procedentes las sanciones". JUAN David Gutiérrez R., El caso ANDEVIP [Asociación Nacional de Entidades de Seguridad Privada] (tercera entrega), Derecho y Politica de Libre Competencia en América Latina (marzo de 2010). Disponible en: http://lalibrecompetencia.com/2010/03/17/el-caso-andevip-terceraentrega/, http://lalibrecompetencia.com/2010/03/07/el-caso-andevip-segunda-entrega/, http:// lalibrecompetencia.com/2010/03/05/el-caso-andevip-primera-entrega/

55 Prueba de ello es que en el caso Valme, la Superintendencia fue enfática en afirmar que la aplicación de las disposiciones sobre prácticas comerciales restrictivas no tiene como requisito sine qua non que los agentes económicos obren de "buena o mala fe", por lo tanto "no se requiere la intencionalidad en la conducta desplegada por los agentes económicos; basta simplemente demostrar la potencialidad de causar daño — objeto-, independientemente del aspecto volitivo, de carácter doloso o culposo que hubiese podido tener el sujeto. Así bien, en la presente actuación administrativa no se ha señalado que la actuación de los investigados hubiese sido dolosa; no obstante, tal circunstancia no exime de responsabilidad frente al incumplimiento de las normas que comprenden el régimen de protección de la libre competencia económica (...)". Y complementa diciendo: "Aceptar una interpretación diferente de las normas de libre competencia equivaldría a exonerar de responsabilidad a aquella persona que realiza un cartel para aumentar los precios con la simple intención de beneficiar una industria que se encuentra pasando por un momento económico difícil, y sin la intención de perjudicar a los consumidores, lo cual es a todas luces contrario al régimen de libre competencia" (...). "De igual manera, debe recordarse que el principio de buena fe no exime de responsabilidad a los agentes del mercado frente al cumplimiento de las normas que protegen la libre competencia". Superintendencia de Industria y Comercio, Resolución 40875 de 2013.

56 Muestra de ello es la resolución de Firmas de Ingeniería, en donde la Superintendencia a propósito del tema del tipo de responsabilidad aplicable en caso de prácticas comerciales restrictivas, hace un análisis confuso y contradictorio del tema, al traer a colación la ya mencionada y célebre sentencia ANDEVIP, afirmando con ello, aparentemente, la no aplicación del régimen de responsabilidad objetiva al decir: "Así las cosas, el Consejo de Estado reconoce que es improcedente la aplicación de responsabilidad objetiva para este tipo de caso, pero a su vez confirma que las conductas catalogadas en el Decreto 2153 establecen un claro componente 


\section{Ahora, en cumplimiento del axioma de interpretación restrictiva de las normas prohibitivas ${ }^{57}$ que permean el derecho administrativo}

subjetivo en el tipo, que de encontrarse demostrado elimina cualquier noción objetiva de la responsabilidad". Ahora, no obstante esta afirmación categórica, con posterioridad afirma: "Así las cosas, la SIC debe demostrar la existencia del acuerdo y que el mismo tuvo como potencialidad u objeto la colusión en el proceso de selección estudiado. Lo anterior, sin que en ningún momento se deba demostrar la intención de los agentes"; parece entonces que con esta afirmación se está más cerca de un régimen de responsabilidad objetiva, sin embargo finaliza indicando que: "Ahora bien, pese a no ser necesaria la demostración de la intención de las partes, la conducta de la misma desplegada por los investigados deja ver cuál era su verdadera intención, la cual, tal y como lo demostró la Delegatura y lo recapituló este Despacho, es totalmente opuesta a la de un agente en competencia con verdaderas intenciones de competir y hacerse con el contrato en contienda". Superintendencia de Industria y Comercio, Resolución 83037 de 2014. Resulta entonces contradictorio el análisis de la Superintendencia - al igual que la posición del Consejo de Estado en la sentencia ANDEVIP - y demuestra con ello que al menos en Colombia, no es clara la aplicación de un régimen de responsabilidad objetiva o subjetiva, al tratarse de prácticas comerciales restrictivas.

Empero, la Superintendencia ha sido mucho más clara respecto al tipo de responsabilidad aplicable a las personas naturales pero en su calidad de representantes legales, pues en esos casos sí ha determinado que a estas se les aplica una de tipo subjetivo, al indicar en el caso Nule Bienestarina que: "No obstante lo anterior, debe este Despacho dejar absolutamente claro que la responsabilidad que se les imputa a las personas naturales sancionadas en el acto administrativo recurrido no es de ninguna forma objetiva, tal y como lo ha señalado en diversas oportunidades. En efecto, es claro que la sanción impuesta a Antonio José Rodríguez Jaramillo y Luis Rafael Monterrosa Ricardo no corresponde a la aplicación de responsabilidad objetiva, comoquiera que al ordenarse la apertura de la investigación en su contra, se solicitaron las explicaciones pertinentes, se les brindó la oportunidad para solicitar y allegar pruebas para desvirtuar los hechos imputados, así como para efectuar las observaciones al Informe Motivado. Finalmente mediante decisión motivada y con base en las pruebas obrantes en el expediente, se determinó que al menos toleraron una práctica restrictiva de la competencia, decisión que les fue notificada en los términos previstos en la ley y con indicación de los recursos procedentes, los cuales ahora se resuelven. A tal conclusión se llegó con base en la participación que cada uno de ellos tuvo en el proceso de contratación en cuestión". Y agrega: "En adición a lo anterior debe precisarse que si bien es claro que las investigaciones administrativas llevadas a cabo por esta Superintendencia no pueden culminar con una interpretación netamente objetiva de la responsabilidad de los representantes legales, también lo es que la misma ley les imprime a dichos cargos un carácter especial que implica un deber adicional de diligencia y cuidado frente al cumplimiento de las normas legales". Superintendencia de Industria y Comercio, Resolución 68972 de 2013.

57 Consejo de Estado, Sala de lo Contencioso Administrativo, Sección Tercera, expediente 14652, Sentencia del 11 de septiembre de 2003, consejero ponente Ricardo Hoyos-Duque. Consejo de Estado, Sala de lo Contencioso Administrativo, Sección Tercera, Radicación 30832, Sentencia del 30 de noviembre de 2006, consejero ponente Alier Hernández-Enríquez, Aclaración de voto: Ramiro Saavedra: "En efecto, la interpretación de las leyes puede realizarse mediante diversos métodos, entre otros, el exegético, sistemático, sociológico, teleológico o finalista, y en todos estos eventos la ley se aplica a un caso realmente contemplado en ella... En tratándose de inhabilidades, incompatibilidades o prohibiciones no es dable aplicar la ley que las establece por analogía, esto es, a eventos no previstos en ella, pero sí es procedente interpretar la ley correspondiente, para determinar su contenido. Así, cuando una norma establece prohibiciones o limitaciones puede ser interpretada para su aplicación, pero no puede ser aplicada analógicamente. De manera que la interpretación finalista o teleológica, debe conducir al intérprete a cobijar aquellas situaciones que están ínsitas en el supuesto lógico de la norma". Consejo de Estado, Sala de lo Contencioso Administrativo, Sección Tercera, Radicación 30832, Sentencia del 30 de noviembre de 2006, consejero ponente Alier Hernández-Enríquez, Aclaración de voto: Ramiro Saavedra. 
sancionatorio, es claro que para tipificar como conducta colusoria un acuerdo, el mismo debe enmarcarse dentro de cada uno de los supuestos precisados en esta norma ${ }^{58}$. Esto es:

\section{O que el acuerdo tenga por objeto la colusión en las licitaciones o concursos}

\section{Este caso la conducta se restringe a que el acuerdo tenga por objeto} la colusión en dos formas de selección de contratistas, a saber: licitación pública y concurso ${ }^{59}$. De esta manera, en este caso, se excluirían los acuerdos que tengan por objeto la colusión en modalidades de selección distintas a las descritas, es decir, selección abreviada y mínima cuantía ${ }^{60}$.

\section{Por lo anterior, resulta curioso que la Superintendencia afirme} que "se tiene que el ordenamiento colombiano condena tanto las conductas que tengan por objeto la colusión en procesos de selección

58 "El principio de legalidad de las sanciones exige que estas estén determinadas en el momento de cometer la infracción. Quien lleva a cabo una conducta legalmente prohibida bajo apremio de sanción penal o administrativa debe conocer previamente cuál es el castigo que acarrea su comportamiento. Este castigo no puede quedar a la definición ulterior de quien lo impone, pues tal posibilidad desconoce la garantía en contra de la arbitrariedad. Así pues, las sanciones deben estar legalmente determinadas taxativa e inequívocamente en el momento de comisión del ilícito, sin que el legislador pueda hacer diseños de sanciones 'determinables' con posterioridad a la verificación de la conducta reprimida. Esta posibilidad de determinación posterior ciertamente deja su señalamiento en manos de quien impone la sanción, contraviniendo el mandato superior según el cual deber ser el legislador quien haga tal cosa... Es decir, el principio de legalidad de las sanciones exige: (i) que el señalamiento de la sanción sea hecho directamente por el legislador; (ii) que este señalamiento sea previo al momento de comisión del ilícito y también al acto que determina la imposición de la sanción; (iii) que la sanción se determine no solo previamente, sino también plenamente, es decir que sea determinada y no determinable. Obviamente, esto no impide que el legislador diseñe mecanismos que permitan la gradación de la sanción, como el señalamiento de topes máximos o mínimos". Corte Constitucional, Sentencia C-475-04, 18 de mayo de 2004, magistrado ponente Marco Gerardo Monroy-Cabra. Disponible en: http://www.corteconstitucional.gov.co/relatoria/2004/c-475-04 htm

59 El numeral 9 del artículo 47 del Decreto 2153 de 1992 se expide en vigencia del Decreto 222 de 1983 (que para la época regía la contratación estatal en Colombia), que establecía dos mecanismos de selección: la licitación y el concurso de méritos (artículos 28 y 39 del Decreto 222 de 1983), duplicidad esta que se mantuvo en la Ley 80 de 1993 (artículo 30), pues les asigna un mismo procedimiento a estas dos formas de selección, lo cual explicaría por qué la norma del Decreto 2153 de 1992 se refiere indistintamente a la licitación o al concurso. Con la expedición de la Ley 1150 de 2007, se eliminan en el artículo 32 las expresiones "concurso" y "términos de referencia", y el concurso de méritos se establece como una forma de selección propia e independiente de selección. Así entonces en nuestra opinión, cabe la posibilidad de que se mire su aplicación a la modalidad de selección del concurso de méritos.

60 No nos referimos a la contratación directa, por cuanto no concebimos una forma en la cual podría concretarse un acuerdo colusorio en esta modalidad de selección, pues la pluralidad es uno de los elementos que exigen los acuerdos restrictivos de la competencia. 
$(\ldots)^{\prime 61}$ (negritas por fuera del texto). En nuestro parecer, esta interpretación no resulta ajustada a la norma, ya que desde el punto de vista del objeto, esta limita la conducta a la licitación o concurso; por lo tanto no resulta adecuado que la Superintendencia la extienda a otras formas de selección no contempladas por ella ${ }^{62}$.

En todo caso, cuando quiera que un acuerdo tenga como objeto alterar ilícitamente una forma de selección distinta a las ya enunciadas, ello no quiere decir que esta conducta - reprochable - quede por fuera de la sanción del derecho de la competencia, pero en este caso se sancionaría en virtud de la prohibición general establecida tanto en el artículo 1 de la ley 155 de $1959^{63}$ como en el artículo 46 del Decreto $2153^{64}$ y no la del numeral 9 del artículo 47 del Decreto 2153 de $1992^{65}$.

Ahora bien, comoquiera que la norma no limita su aplicación al campo público, también podría aplicarse a las licitaciones o concursos que se presenten en el ámbito privado o en aquellas en-

61 Superintendencia de Industria y Comercio, Resolución 40901 de 2012.

62 En armonía con esta posición parece estar el Proyecto de ley 038 de 2015 pues modifica el artículo 27 del Estatuto Anticorrupción (Ley 1474 de 2011), al ampliar el rango de acción de la sanción penal a "El que en un proceso de contratación pública (...)", y ya no lo restringe a licitación pública, subasta pública, selección abreviada o concurso. Sin embargo, la misma previsión no se hizo respecto al numeral 9 del artículo 47 del Decreto 2153 de 1992, por lo que mantenemos nuestras críticas al respecto.

63 Ley 155 de 1959, "Artículo 1. Modificado por el artículo 1, Decreto 3307 de 1963. El nuevo texto es el siguiente: Quedan prohibidos los acuerdos o convenios (sic) que directa o indirectamente tengan por objeto limitar la producción, abastecimiento, distribución o consumo de materias primas, productos, mercancías o servicios nacionales o extranjeros, y en general, toda clase de prácticas, procedimientos o sistemas tendientes a limitar la libre competencia y a mantener o determinar precios inequitativos". Colombia, Ley 155 de 1959, por la cual se dictan algunas disposiciones sobre prácticas comerciales restrictivas, 30138 Diario Oficial, 22 de enero de 1960. http://www.alcaldiabogota.gov.co/sisjur/normas/Norma1.jsp?i=38169

64 Artículo 46 del Decreto 2153. "Prohibición. En los términos de la Ley 155 de 1959 y del presente Decreto están prohibidas las conductas que afecten la libre competencia en los mercados, las cuales en los términos del Código Civil, se consideran de objeto ilícito (...)". Colombia, Decreto 2153 de 1992, por el cual se reestructura la Superintendencia de Industria y Comercio y se dictan otras disposiciones, 40.704 Diario Oficial, 31 de diciembre de 1992. Disponible en: http://www.secretariasenado.gov.co/senado/basedoc/decreto_2153_1992.html

65 Esto tampoco significa que el acuerdo no puede ser sancionado penalmente, pues como veremos más adelante, el artículo 27 del Estatuto Anticorrupción sí contempló un margen más amplio para la aplicación de la conducta. Así las cosas, comoquiera que nos encontramos ante jurisdicciones distintas, el hecho de que el acuerdo competitivo no se sancione por violación del numeral 9 del artículo 47 del Decreto 2153 de 1992, sino por la prohibición general, no es óbice para que el acuerdo colusorio cometido en un proceso de selección diferente a la licitación o concurso, sea sancionado penalmente. En todo caso, es posible que se generen decisiones contradictorias pues los supuestos que contemplan ambas normas son distintos, por lo tanto, puede llegar a darse el caso en que la conducta se sancione administrativamente pero no penalmente y viceversa. 
tidades no sometidas al Estatuto General de Contratación en los que se establezca algún tipo de concurso.

\section{O que el acuerdo tenga como efecto la distribución de adjudicaciones de contratos ${ }^{66}$, distribución de concursos o fijación de términos de las propuestas ${ }^{67}$}

Esta descripción de la conducta implica un mayor rango de aplicabilidad, ya que la técnica legislativa empleada no se restringió a una modalidad de selección específica, sino que por el contrario, se dirigió de manera general a los efectos dañinos a la competencia que los acuerdos colusorios provocan.

Así entonces, desde el punto de vista del efecto, se podrán sancionar aquellos acuerdos que se presenten en cualquier modalidad de selección e incluso en procesos contractuales privados.

No obstante todo lo anterior, debemos reiterar que nuestra posición contrasta con la de la Superintendencia de Industria y Comercio, pues esta entidad en diversas resoluciones ${ }^{68}$ ha venido estudiando la posible comisión de acuerdos colusorios en diversos procesos de selección, sin restringirlo a la licitación o al concurso. Al respecto, consideramos que se trata de un comportamiento que no solamente resulta lesivo de los principios que gobiernan el derecho administrativo sancionador - por las razones que ya anotamos con anterioridad - sino que además genera un gran riesgo jurídico para la entidad.

66 "Esta forma de colusión tiene como sujetos las empresas interesadas en presentar propuestas, que de manera acordada escogen entre ellas el agente económico que presentará la mejor propuesta, introduciendo en cada propuesta los elementos que la hacen más atractiva, lo que deja sin posibilidad de una verdadera escogencia a la empresa interesada en los servicios". Mauricio Velandia, Derecho de la competencia y del consumo, 158-159 (2 $2^{\mathrm{a}}$ ed., Universidad Externado de Colombia, Bogotá, 2011).

67 "La conducta que se reprime consiste en elaborar unos pliegos que no permitan la igualdad de oportunidades para los posibles participantes, pues por medio de estos puede la licitación estar dirigida para que uno de ellos se vea favorecido. En tal instancia la empresa o la persona encargada de elaborar los pliegos acuerda con uno de los potenciales contratistas la adjudicación del contrato, diseñando en conjunto un pliego que beneficiará al partícipe del acuerdo. Además de ser restrictiva puede llegar a ser desleal”. Mauricio Velandia, Derecho de la competencia y del consumo, 159 ( $2^{\mathrm{a}}$ ed., Universidad Externado de Colombia, Bogotá, 2011).

68 Nos referimos, por ejemplo, a las resoluciones 53991 de 2012, 40875 de 2013 y 53914 de 2013, en las que se sanciona la realización de acuerdos colusorios en los procesos de selección abreviada. 


\section{Que dicho acuerdo afecte el bien jurídico protegido}

Finalmente, en cuanto a los intereses involucrados, el artículo 3 de la Ley 1340 de 2009 establece de manera precisa los bienes jurídicos protegidos por el derecho de la competencia en Colombia, vale decir: la libre participación de las empresas en el mercado, el bienestar de los consumidores y la eficiencia económica. Estos valores deben ser tomados en cuenta a la hora de determinar si una conducta es significativa ${ }^{69}$ y por lo tanto si amerita la apertura de una investigación administrativa ${ }^{70}$.

\section{FORMAS MÁs COMUNES DE COLUSIÓN}

Una vez analizada la definición de colusión y de los supuestos que deben converger para la configuración de la conducta, corresponde a continuación examinar algunas de las formas más comunes de manipulación que pueden llevar a cabo los oferentes en un proceso de selección. Veamos algunas ${ }^{71}$ :

\section{A. Supresión de la oferta (bid suppression)}

Esta estrategia consiste en que uno o más competidores que se esperaría que compitieran entre sí dentro de un proceso contractual acuerdan: 1) que uno o varios de ellos se abstendrán de presentar su oferta pese a cumplir todas las condiciones para ello; 2) presentan la oferta pero pactan su retiro, lo cual pretende favorecer al ganador designado en el acuerdo; 3) presentan una oferta conjunta aun cuando podrían haberlo hecho de manera independiente.

69 Respecto a lo que debe entenderse por significatividad, remitimos al Concepto 25057 del 21 de marzo de 2013, emitido por la Superintendencia de Industria y Comercio.

70 Llama la atención este punto, pues ni en la Ley 155 de 1959 ni en el Decreto 2153 de 1992 se realizaba una consagración en este sentido.

71 Sobre este particular, remitimos tanto a la página oficial de la OCDE (Organización para la Cooperación y el Desarrollo Económicos, OCDE, Lineamientos para combatir la colusión entre oferentes en licitaciones públicas, 2 (febrero de 2009). Disponible en: www.oecd.org, http://www.oecd.org/daf/competition/cartels/42761715.pdf) como a la página de la División Antitrust del Departamento de Justicia de Estados Unidos (Estados Unidos, Department of Justice, Antitrust Division, Price Fixing, Bid Rigging, and Market Allocation Schemes: What They Are and What to Look For. An Antitrust Primer. Disponible en: http://www.justice.gov/ atr/public/guidelines/211578.pdf), por tratarse de dos organismos que han desarrollado en extenso este tema. 
Esta forma de manipulación fue advertida en el caso Intersystem $^{72}$, investigación que inició a raíz de la denuncia presentada por la Veeduría Distrital, de Bogotá. Durante la etapa de averiguación preliminar, al ser interrogados, los denunciados aceptaron la existencia de un acuerdo previo a la presentación de las ofertas, consistente en que si bien tanto la sociedad como las personas naturales se postulaban al proceso contractual, una vez seleccionados, se ponían de acuerdo respecto a cuál de los oferentes debía presentar la propuesta y quiénes debían retirarse.

Si bien no en todos los casos se logró la adjudicación del contrato, en sentir de la Superintendencia, los participantes del acuerdo sí aumentaron sus posibilidades de resultar adjudicatarios, lo cual para la entidad era completamente reprochable, en la medida en que con esa conducta se evitó que las instituciones educativas contaran con un mayor número de ofertas a evaluar y a su vez, disminuyeron las posibilidades de quienes no hacían parte del acuerdo de resultar seleccionados para presentar sus propuestas; ello afectó tanto el mercado como el propio proceso de selección.

\section{B. Ofertas complementarias o de resguardo (complementary bidding, cover bidding o "courtesy" bidding)}

También son conocidas con el nombre de ofertas complementarias, de cortesía o simbólicas, las cuales se pueden presentar en una de las siguientes modalidades: 1) los competidores se ponen de acuerdo para presentar ofertas con precios demasiado altos o bajos como para ser aceptadas ${ }^{73}$; 2) acuerdan presentar una oferta más alta que la del que ha sido designado para ser el ganador; 3) presentan ofertas que no cumplen los parámetros del pliego, con el objeto de que sean rechazadas; 4) las empresas u oferentes son seleccionados pero solo uno de ellos presenta la propuesta.

72 Superintendencia de Industria y Comercio, Resolución 1055 de 2009.

73 Por ejemplo, en el caso Valme, la Superintendencia encontró que el Consorcio H\&F presentó una propuesta atípicamente baja, lo que hizo que el cálculo de la media aritmética disminuyera y favoreciera la oferta de Valme. De esta manera, la oferta del Consorcio H\&F no tenía el objetivo de competir para obtener la adjudicación del contrato dentro del proceso de selección, sino el de servir de instrumento para el éxito de Valme Ltda. en el proceso. Superintendencia de Industria y Comercio, Resolución 40875 de 2013. 
La oferta cumplirá entonces el objetivo de dar la apariencia de haber ocurrido en un escenario de competencia, cuando verdaderamente ello no ha sido así.

Esta forma de manipulación ha sido ampliamente analizada por la Superintendencia de Industria y Comercio. En esta clase de acuerdos hay un común denominador: la presencia de una o varias ofertas complementarias, de resguardo o simbólicas — sin ninguna posibilidad de resultar ganadoras_-, para dar la apariencia de competencia y servir de complemento a la propuesta que busca resultar adjudicataria del proceso de selección.

Un ejemplo de esta forma de manipulación se presentó en el caso Consorcio Vial Colombiano y el Consorcio de Oriente, investigación que se originó a partir de la puesta en conocimiento por parte del Fondo Financiero de Proyectos de Desarrollo, FONADE, de las observaciones al informe de evaluación presentadas por la empresa Conconcreto S.A. respecto a algunas coincidencias halladas en las ofertas de los investigados en un proceso de licitación. En este caso, la Superintendencia planteó varios escenarios en los cuales resultase posible concebir un modelo que, bajo una serie de supuestos, permitiera establecer que la conducta colusoria de los investigados pudo tener un respaldo o complementación matemática que les permitió asegurar la adjudicación del contrato, teniendo como origen una conducta colusoria. Bajo ese supuesto, el Despacho concluyó que en efecto en la mayoría de los escenarios planteados y gracias al acuerdo obrante entre los investigados, se aumentaron significativamente sus probabilidades de resultar adjudicatarios ${ }^{74}$.

Ahora, también resulta interesante traer a colación el caso INPEC, cuyo objeto era contratar la prestación del servicio de alimentación por el sistema de ración para la atención de los internos de los centros de reclusión del orden nacional. En este caso, para la Superintendencia, la forma de colusión de los investigados correspondió a la siguiente estructura: mientras que dos de los investigados presentaron una oferta baja idéntica, el tercero presentó una oferta que en todos los casos resultaba más alta que las dos coincidentes. De esa manera, las ofertas idénticas y con un precio bajo no fueron reales, sino complementarias o de resguardo

74 Superintendencia de Industria y Comercio, Resolución 64400 de 2011. 
para aumentar las probabilidades de adjudicación de la tercera propuesta, aun en presencia de otros oferentes, lo cual afectó artificialmente el cálculo de la media aritmética y así la propuesta más alta logró la adjudicación. En este asunto, la Superintendencia realizó una serie de análisis probabilísticos y concluyó en todos los casos la existencia de un pacto colusorio que ayudó a maximizar las opciones de adjudicación de los ítems bajo investigación. De esta manera, las simulaciones realizadas demostraron que la estructura de las ofertas coludidas otorgó la victoria en el ítem al oferente coludido de la oferta alta con un grado de probabilidad extremadamente elevado.

Otra investigación interesante en relación con el tema que nos ocupa es la del caso Cárceles, la cual se originó en la solicitud de la Secretaría General del Ministerio del Interior y de Justicia, por las posibles conductas irregulares llevadas a cabo por algunos proponentes que participaron en un proceso de selección abreviada adelantado por esa entidad: la propuesta de uno de los proponentes fue suscrita por el representante legal suplente; algunas empresas presentaron más de una propuesta; antes del cierre, el representante legal principal de una de las uniones temporales participantes (UT Cárceles 2008) solicitó el retiro de la propuesta, mientras que el suplente pidió hacer caso omiso de ella. Ante estas irregularidades, la Superintendencia de Industria y Comercio inició investigación y concluyó que la propuesta allegada por la UT Cárceles 2008 fue una propuesta simbólica y/o complementaria que no buscó la adjudicación del contrato, sino aparentar un escenario de competencia, pues no era una propuesta real sino producto del acuerdo colusorio que buscó favorecer como adjudicatario a la UT Seguridad Carcelaria. Para explicar este argumento, la Superintendencia se fundamentó en el hecho de que, pese a que la representante legal suplente de la UT Cárceles 2008 sabía que las empresas EBC y Control Box no estaban interesadas en participar con esa UT, esta de manera unilateral decidió seguir adelante con la presentación de la propuesta, no para buscar la adjudicación del contrato - puesto que resultaba evidente que la propuesta no cumplía los requisitos del pliego-, sino para descalificar a la UT Protección Integral Carcelaria, dado que el propio pliego de condiciones no permitía que una empresa 
presentara más de una propuesta, conducta con la que benefició a la UT Seguridad Carcelaria, adjudicataria del contrato ${ }^{75}$.

\section{Rotación de ofertas (bid rotation)}

A diferencia de la modalidad anterior, en este supuesto los oferentes sí presentan sus ofertas pero se turnan para ser el oferente ganador. Los términos en que se presenta la rotación pueden variar, por ejemplo, pueden turnarse el contrato de acuerdo a su tamaño, o asignar un número igual de contratos a cada conspirador, o que cada empresa obtenga los mismos ingresos a largo plazo.

Por lo tanto, en este caso, las autoridades buscarán los patrones de rotación de las ofertas que pueden evidenciar la existencia de un acuerdo.

Esta clase de colusión resulta mucho más difícil de detectar, pues la rotación no necesariamente se dará respecto a los contratos de una sola entidad contratante. En esa medida, la autoridad de competencia requerirá llevar un control de los procesos contractuales en los que los agentes coludidos han presentado propuestas para evidenciar un posible patrón de conducta, lo que en la práctica no será tan fácil de realizar.

Actualmente, cursa en Colombia una investigación por este tema en el famoso caso Empresas de Seguridad y Vigilancia Privada, en donde la Superintendencia de Industria y Comercio, SIC, formuló pliego de cargos en contra de 8 empresas de vigilancia y seguridad privada y de 32 personas naturales. Este caso se inició a raíz de la denuncia presentada por el Instituto Colombiano de Bienestar Familiar, ICBF, al identificar una supuesta manipulación del proceso contractual, pues aun cuando los oferentes aparentemente operaban como participantes individuales, realmente actuaban de manera coordinada en la presentación de sus ofertas. Una vez adelantadas las primeras visitas administrativas, la Superintendencia detectó que los presuntos actos de colusión no solamente se habrían presentado en el proceso denunciado, sino en otros 252 procesos de contratación pública adelantados ante 149 entidades estatales, durante 2010, 2011 y 2012; en este tiempo, según la Delegatura

75 Superintendencia de Industria y Comercio, Resolución 53991 de 2012. 
para la Protección de la Competencia, se habrían concertado y ejecutado cientos de acuerdos anticompetitivos mediante diversas estrategias y con la utilización de diferentes empresas, que simulando ser oferentes independientes falsearon la competencia en el mercado al tratarse realmente de un solo proponente; por este motivo se decidió abrir investigación mediante la Resolución 2065 de 2015. Se trata de una de las investigaciones más grandes que se han abierto en Colombia por colusión en licitaciones y la primera en la que una persona natural se acoge al programa de beneficios por colaboración por la participación en un acuerdo colusorio.

\section{Acuerdo de precios}

Las empresas acuerdan presentar sus propuestas bajo condiciones previamente definidas y conciertan los precios de sus ofertas; esto con el objetivo de alcanzar un precio superior al que se derivaría de un proceso de selección en el que estuvieran forzadas a competir por este factor; en estos casos, por ejemplo, los partícipes pueden acordar precios mínimos de participación por unidad o globales, o bien aplicar una misma fórmula para el cálculo de precio, entre otras.

Colombia no ha sido ajena a esta clase de acuerdos; muestra de ello es la sanción impuesta en el caso Valme $^{76}$, en la cual la Superintendencia de Industria y Comercio sancionó a Valme Ltda. y al Consorcio H\&F por llevar a cabo un acuerdo tendiente a establecer los precios que cada uno ofrecería dentro del proceso de selección adelantado por la Gobernación de Arauca.

\section{E. Acuerdos de reparto o asignación de mercado}

Los partícipes llegan a un consenso respecto al oferente que presentará la propuesta ganadora y se turnan de manera que cada uno de ellos gane una cierta cantidad de contratos por un valor previamente acordado, para aparentar un escenario de competencia.

En ese contexto, se puede presentar un reparto de mercado por región, por producto o por tipo de cliente, de manera que se aumentarán las probabilidades de que la licitación sea adjudicada, en la

76 Superintendencia de Industria y Comercio, Resolución 40875 de 2013. 
medida en que los demás oferentes se comprometerán a abstenerse de participar en aquellas licitaciones que han sido asignadas a otro participante o presentarán ofertas de resguardo.

1. En el ya mencionado caso INPEC, la Superintendencia también identificó un posible reparto de mercado entre los agentes coludidos; para ello se basó en los interrogatorios practicados a los investigados, con los cuales la entidad pudo establecer que estos se repartieron los ítems, de forma que el ganador lograra continuar con los contratos de los centros penitenciarios en los cuales ya había sido contratista.

\section{F. Subcontratación (subcontracting)}

Esta - más que una forma de colusión — puede constituir una señal de alerta o indicio acerca de la posible comisión de un acuerdo colusorio entre los participantes en un proceso de selección.

Se ha entendido más bien como una forma de recompensar a quien ha hecho parte de un acuerdo colusorio - ya sea retirando una oferta o presentando una oferta que no será escogida-, por medio de la subcontratación o la celebración de contratos de suministro o cualquier otra modalidad que garantice que los no ganadores serán parte del contrato que ha sido asignado como resultado de un acuerdo colusorio. Esto asegura el reparto de los beneficios económicos derivados del mismo.

Todas estas formas de manipulación de los procesos de selección de contratistas cuentan con un ingrediente en común: un acuerdo entre todos o algunos de los oferentes que busca designar el ganador, al eliminar o establecer limitaciones o barreras a la competencia.

\section{Circunstancias gUe PUEDen PROPICIAR LA CONSOLIDACIÓN DE ACUERDOS COLUSORIOS}

Estas formas de colusión de las que hemos venido hablando, por lo general, se ven facilitadas en escenarios en los que los oferentes pueden establecer un control sobre los acuerdos a los que han llegado, pues sin lugar a dudas para que un acuerdo de colusión 
resulte exitoso, las empresas participantes deben implementar un conjunto de medidas que permitan darle seguimiento.

En este sentido, por ejemplo, en sus Directrices sobre la evaluación de las concentraciones horizontales con arreglo al Reglamento del Consejo sobre el control de las concentraciones entre empresas, la Comisión Europea ha establecido tres condiciones que favorecen la coordinación entre empresas ${ }^{77}$. La primera de ellas apunta a la necesidad de que las empresas coordinadas puedan ejercer un control suficiente sobre el cumplimiento de las condiciones del acuerdo; la segunda requiere la existencia de mecanismos que disuadan a los participantes del acuerdo de incumplirlo, esto es, la imposición de sanciones y castigos a aquellos que no cumplan el acuerdo; y en tercer lugar, los resultados esperados de la coordinación deben estar al abrigo de las reacciones que puedan esperarse, tanto de los competidores actuales como de los que en el futuro se puedan $\operatorname{presentar}^{78}$.

Aunque la colusión puede presentarse en cualquier mercado, algunos factores pueden fomentarla, entre ellos:

- La presentación de un número reducido de compañías a la licitación o que cumplen los requisitos exigidos por el pliego, puede fomentar la presencia de estos acuerdos en la medida en que el número de oferentes que participarán en el proceso será menor, lo cual facilitará su control.

- La presencia de asociaciones o agremiaciones - las cuales son lícitas, pero en ocasiones se utilizan para fines no adecuados o anticompetitivos - puede facilitar la comunicación entre com-

77 Unión Europea, Directrices sobre la evaluación de las concentraciones horizontales con arreglo al Reglamento del Consejo sobre el control de las concentraciones entre empresas (2004/C 31/03), Diario Oficial de la Unión Europea, 9, 5 de febrero de 2004. Disponible en: http://eur-lex.europa.eu/legal-content/ES/TXT/?uri=URISERV\%3A126107

78 "Para que la coordinación resulte exitosa, es preciso que el resultado esperado de la misma esté a salvo de la actuación de las empresas no coordinadas y de los competidores potenciales, así como de los clientes. Por ejemplo, si la coordinación pretende reducir la capacidad global en el mercado, esto solo perjudicará a los consumidores si las empresas que no se coordinan son incapaces o no tienen ningún incentivo para responder a esta reducción mediante un aumento suficiente de su propia capacidad que evite una disminución neta de la capacidad o al menos consiga que la reducción de capacidad coordinada no sea rentable". Unión Europea, Directrices sobre la evaluación de las concentraciones horizontales con arreglo al Reglamento del Consejo sobre el control de las concentraciones entre empresas (2004/C 31/03), Diario Oficial de la Unión Europea, 11, 5 de febrero de 2004. Disponible en: http://eur-lex.europa.eu/ legal-content/ES/TXT/?uri=URISERV\%3A126107 
petidores y con ello, la consolidación de esta clase de acuerdos y su ocultamiento ${ }^{79}$.

- La existencia de pliegos de condiciones repetitivos aumenta las probabilidades de colusión, pues los oferentes pueden prever los requisitos que exigirá la administración y así acordar cuál de los participantes presentará la oferta ganadora ${ }^{80}$.

- Ciertas figuras contractuales - como los acuerdos de colaboración, consorcios ${ }^{81}$, uniones temporales, grupos empresariales ${ }^{82}$ pueden facilitar la conformación de acuerdos, en la medida en que es frecuente que los oferentes acudan a estas figuras para presentarse a licitar. De esta manera, podría propiciarse que

79 "Un tema que suele cobrar relevancia adicional en el encuadramiento jurídico de los casos de colusión es la acción de las cámaras y asociaciones empresariales y profesionales. Este tipo de instituciones, cuyo objetivo principal es asumir la representación de un sector en sus reclamos y negociaciones con el gobierno y con los sindicatos de trabajadores, así como propender al mejoramiento de las actividades a las que se dedican sus miembros, suele servir en ciertas circunstancias como el instrumento más eficaz (y, a veces, indispensable) para llevar a cabo prácticas de carácter colusivo. Así, ciertos acuerdos de precios y cantidades o repartos de mercados pueden surgir de disposiciones emanadas de una cámara o asociación empresarial o profesional, la cual puede tener también la función de 'vigilante del cartel', detectando los incumplimientos y sancionando a las empresas o profesionales que se apartan del acuerdo colusivo prescrito. Las asociaciones pueden cumplir también un papel menos activo pero igualmente importante, como lo es el de facilitar la comunicación entre las empresas de un sector y la de difundir entre ellas". Germán Coloma, Defensa de la competencia. Análisis económico comparado, 88 (Ciudad Argentina, Buenos Aires, 2003).

80 Este aspecto, por ejemplo, se analizó en la Resolución 25798 de 11 de septiembre de 2003, por medio de la cual la Superintendencia de Industria y Comercio dio apertura a una investigación al encontrar que "es claro que el hecho de que los proponentes conozcan con anterioridad el mecanismo de selección, y que cuenten con [1a] información histórica sobre el comportamiento habitual de los proponentes en licitaciones con mecanismo de asignación de puntaje similares al presente, hace relativamente simple que dos o más proponentes puedan establecer acuerdos para presentar ofertas económicas en condiciones tales que uno de ellos se asegure [de] que, en cualquier caso, la licitación le será adjudicada".

81 Esta fue una de las evidencias analizadas por la Superintendencia de Industria y Comercio para sancionar en los casos de Consorcio Vial Colombiano, IDIPRON e INPEC. En opinión de la Superintendencia, llamaba la atención que pese a que en otras licitaciones los proponentes se habían presentado como consorcio, en los procesos de selección bajo investigación, los mismos se presentaron de manera independiente. Si bien, en palabras de la Superintendencia, el hecho de que los proponentes se presentaran previamente de manera conjunta a procesos similares no implicaba por sí mismo una violación al régimen de competencia, sí constituía una alerta en cuanto a un eventual acuerdo colusorio.

82 En este tema, la SIC ha expedido las resoluciones 54693 y 54695 de 2013, mediante las cuales analiza el tema de los grupos empresariales a propósito del denominado "caso Nule" — que en nuestro país ha sido objeto de variados análisis e impulsor de numerosas iniciativas legislativas, entre ellas el Estatuto Anticorrupción-. En estas resoluciones se sanciona a este grupo empresarial por la supuesta utilización de varias empresas integrantes del mismo, con el ánimo de manipular el proceso de selección y así aumentar sus probabilidades de resultar adjudicatarios, lo cual efectivamente sucedió. Así mismo y más recientemente encontramos el caso Empresas de Seguridad y Vigilancia Privada (2015). 
en otros procesos de selección - en los que ya no se presentan juntos-, lleguen a acuerdos colusorios de manera más fácil.

- Hay sectores más sensibles a la consolidación de estos acuerdos en razón a la propia estructura del mercado; por ejemplo, en el caso colombiano, se han identificado cuatro sectores vulnerables, estos son: i) servicios de construcción, reparación y mantenimiento; ii) alimentos, bebidas y tabaco; iii) servicios de defensa nacional, orden público, seguridad y vigilancia; y iv) equipo, accesorios y suministro de oficina ${ }^{83}$. Lo mismo ocurre cuando los bienes o servicios que se pretende contratar tienen pocos o ningún sustituto, o solo un número reducido de proveedores está en capacidad de ofrecerlos, pues así las empresas estarán más dispuestas a realizar acuerdos con la competencia, a efectos de garantizar, ya sea la adjudicación del contrato o por lo menos la percepción de alguna utilidad derivada del mismo.

- De igual forma, se considera que la aplicación irrestricta de principios como el de transparencia puede facilitar la concertación entre oferentes, pues permite que las empresas alineen sus estrategias con mayor facilidad, al controlar el cumplimiento del acuerdo, detectar y castigar cualquier alejamiento a los términos convenidos ${ }^{84}$.

- La imposición de determinada forma jurídica ${ }^{85}$, o las discriminaciones en razón del territorio o la nacionalidad, o la exigencia de requisitos técnicos y económicos innecesarios o excesivos o de certificaciones de calidad, o el requerimiento de un orden específico para la presentación de las ofertas no solamente resultan contrarios al principio de transparencia y al deber de selección objetiva, sino barreras innecesarias a la libre competencia. En

83 Estos son datos proporcionados por la Superintendencia de Industria y Comercio en el marco del Foro Latinoamericano de Competencia. Organización para la Cooperación y el Desarrollo Económicos, OCDE, Foro Latinoamericano de Competencia, Sesión III, Mejorando la eficacia en las licitaciones públicas: combatiendo la colusión y la corrupción, Documento Base, DAF/ COMP/LACF(2012)7, 18 al 19 de septiembre de 2012, República Dominicana, 5. Disponible en: http://www.oecd.org/officialdocuments/publicdisplaydocumentpdf/?cote=DAF/COMP/ LACF(2012)2\&docLanguage $=$ Es

84 Sin embargo, no puede dejarse de lado el hecho de que una menor transparencia en un proceso licitatorio puede a su vez traducirse en un aumento de la corrupción, fenómeno que en nuestro país han tenido un vertiginoso incremento.

85 Un proceso contractual rígido puede favorecer la consolidación de acuerdos colusorios entre los oferentes, a la vez que limita la capacidad de reacción por parte de las autoridades competentes frente a la ocurrencia de estos comportamientos. 
este caso, deberían preverse sanciones para la entidad pública por no fomentar escenarios de competencia.

- Cierto sector de la doctrina considera que un procedimiento contractual abierto, en que se permita la participación de cualquier oferente, no necesariamente resulta más eficiente ${ }^{86}$, esto en la medida en que el mismo puede propiciar la burocracia y resultar mucho más costoso. En efecto, el Estado tendrá que desplegar una buena parte de sus recursos humanos, técnicos y presupuestales con miras a evaluar todas las propuestas que se presenten a fin de poder escoger la que se ajuste en mayor medida al objetivo buscado por el proceso licitatorio y, el contratista, a su turno, deberá invertir todos los medios que estén en su poder para demostrar que su oferta es la que más se adecúa a las necesidades de la Administración, sin que su esfuerzo se traduzca necesariamente en la adjudicación del contrato. En respuesta a estas falencias, se promueve la estructuración de procesos de licitación restringidos o negociados, en donde no se permita la entrada de cualquier oferente, sino previa invitación por parte del Estado o en un escenario en el que Estado y particular negocien las condiciones del contrato ${ }^{87}$.

- Por su parte, los detractores de esta postura abogan por la transparencia e igualdad que promueve la licitación abierta, así como

86 "En este orden de ideas, si bien el procedimiento de selección abierto o público tiene el potencial de garantizar que todos los interesados sean invitados de manera masiva e indeterminada a presentar ofertas, el procedimiento restringido reduce los costos administrativos y de evaluación, lo que permite, en consecuencia, que las entidades públicas lleven a cabo procedimientos de escogencia de contratistas más rentables. La legalidad y formalidad extrema de los procedimientos ha $[s i c]$ hecho que ante la imposibilidad de flexibilizar los mecanismos se llegue a situaciones que no son justificables desde el punto de vista económico al no reportar ningún grado de eficiencia, a diferencia de lo que ocurre en el sector privado, en donde la agilidad y capacidad de adaptación en cuanto a la selección de opciones deriva en una contratación estratégica". Mónica Sofía Safar-Díaz, Análisis económico de los procedimientos de selección de contratistas del Estado en el derecho colombiano: hacia un mecanismo eficiente y transparente, 6, 22 (Serie Derecho Administrativo 6, Universidad Externado de Colombia, Bogotá, 2009).

87 "The impact of public procurement policies depends on the public purchasing strategy. Three major types of tendering procedures can be distinguished in this strategy. Open procedures are those national procedures by which all interested suppliers or contractors may submit an offer. It provides the greatest opportunity for competition and satisfies the need for efficiency. However, it introduces bureaucracy and is considered a costly procedure. Regarding restricted procedures, only the suppliers selected by the contracting authority are invited to submit tenders. Negotiated procedures refer to procedures by which contracting authorities consult the suppliers (reselected or not) of their choice and negotiate the terms of the contract with one or several of them". Dimitri Mardas, Tendering Procedures and Buy-National Policies, 5 International Advances in Economic Research, 2, 189-203 (1999). Disponible en: http:// findarticles.com/p/articles/mi_hb3090/is_2_5/ai_n28738195/ 
por la libertad de concurrencia, que como principios permiten que los competidores, en igualdad de condiciones ante la Administración, tengan la posibilidad de participar y ser escogidos, para reducir las asimetrías de información y facilitar la vigilancia y control del proceso contractual, a efectos de evitar acuerdos entre los proponentes o actos de corrupción de los funcionarios ${ }^{88}$.

- Finalmente, como mencionamos con anterioridad, se ha reconocido en el ámbito internacional que la colusión presenta sus efectos más adversos en el proceso licitatorio. En efecto, la complejidad de la normativa de este proceso de selección ${ }^{89}$ lo hace un escenario propicio para la concertación de acuerdos entre los

88 "A form of open tendering is provided as the main procurement method in many procurement systems, including under UNCITRAL (see below) —although by no means in all systems. The reasons for this are many. In essence, it may be said that for many transactions in a lot of systems open tendering is considered best to promote and support many of the key objectives of the system because it provides for the greatest degree of transparency and the greatest degree of competition out of all procurement procedures. (...) In addition, open tendering is inherently conducive to the independent objective of equal access for all to the opportunities provided by the government market. In particular, we can note that: I. The possibility in open tendering for any qualified person to have a tender considered makes for the maximum possible number of tenderers, which can increase the chances of the procuring entity benefiting from the best supplier operating on the market and hence improve value for money. II. This same feature of open tendering induces suppliers to put forward the best offer they can make because of the need to beat the offers of many other suppliers to win the contract - again enhancing value for money. III. This same feature of open tendering also reduces the risk of collusion between suppliers since collusion is more difficult with a larger number of bidders, once again enhancing value for money. IV. This same feature of open tendering also ensures that any interested person has access to government business, an important objective in its own right in some procurement systems. V. The absence of a process in which the procuring entity selects which suppliers will and which will not be permitted to submit tenders reduces the possibility of abuse of discretion to favour particular suppliers, to the benefit of both value for money and integrity of the process. VI. The formal nature of open tendering in other respects, including limited possibilities for clarification and negotiation, also reduces the possibility for abuse of discretion and improves the monitoring of the system, again to the benefit of both value for money and integrity of the process". Sue Arrowsmith, Steen Treumer, Jens Fejø \& Lili Jiang, Public Procurement Regulation: An introduction, 34 (The EU Asia Inter University Network for Teaching and Research in Public Procurement Regulation, University of Nottingham, Nottingham, 2011). Disponible en: http://eprints.nottingham.ac.uk/1689/ (negritas fuera del texto).

89 "Así, existe un total de 138 fuentes normativas vigentes que provienen de leyes y decretos; a su vez el catálogo de las fuentes históricas derogadas es de 109. En el universo de fuentes legales y reglamentarias cada inciso, numeral y parágrafo vigente contienen como mínimo un supuesto normativo - hecho y consecuencia jurídica-, que yo denomino regla. En el acumulado de normas aplicables, cerca de 1.350 artículos, se alcanza un número que supera las 3.590 reglas ya mencionadas. Por eso, ante este hecho tan difícil y complejo, me atrevo a llamar la contratación colombiana como rompecabezas". Iván Darío Gómez-LeE, Contratación visible, Manual para un buen control de recursos en la contratación pública, 24 (Auditoría General de la República, Procuraduría General de la Nación, Instituto de Estudios del Ministerio Público, IEMP, Bogotá, 2010). Disponible en: http://www.auditoria.gov.co/Biblioteca_documental/ OEE/AGRP11-Manual_contratacion_visible_vl.pdf 
proponentes o, incluso, entre los proponentes y los funcionarios encargados de la contratación; en la medida en que si bien se trata de un proceso reglado, hay ciertas áreas grises que pueden facilitarse actuaciones poco transparentes, discriminatorias y contrarias a la competencia.

\section{PRUEBA DEL ACUERDO COLUSORIO. LA UTILIZACIÓN DE INDICIOS}

En vista del carácter secreto que predomina en la conformación de acuerdos colusorios, no resulta una tarea fácil para las autoridades de competencia recabar el material probatorio suficiente para establecer su existencia. Lo habitual es que las empresas no hagan explícitos sus acuerdos ni dejen prueba documental alguna, lo que resulta en simples acuerdos verbales en los que por lo general intervienen los rangos más altos de las empresas, de manera que las autoridades solo podrán echar mano de meras pruebas indiciarias, que por sí solas no podrán conducir a una condena contra sus integrantes ${ }^{90}$, sino que requerirán una valoración en conjunto de acuerdo a las reglas de la sana crítica. En muy pocos casos se ha logrado una aceptación de los miembros del acuerdo sobre la comisión de la conducta ${ }^{91}$, lo que hace mucho más difícil el papel de las autoridades a la hora de sancionar estos comportamientos altamente lesivos de la competencia.

En las investigaciones adelantadas por la Superintendencia de Industria y Comercio sobre colusión, esta ha encontrado indicios en la forma en que las empresas presentan sus ofertas, es decir, ha identificado coincidencias en los tipos de letra, en los errores tipográficos, en los precios ofrecidos (aunque las empresas cuentan con costos distintos), en la planta de personal $^{92}$, etc.

90 "Es esencial que los hechos indicadores estén plenamente demostrados para que el indicio pueda tenerse como prueba, porque si ese hecho indicador o básico no está demostrado, es imposible que de él pueda deducirse la existencia del hecho desconocido y que se pretende demostrar por medio del proceso mental que hace el juez, que si parte de una base no puede llevarlo racionalmente a concluir que existe el hecho que se deduce de ciertos antecedentes o circunstancias conocidas". Gaceta Judicial, tomo LXXX, 2154, 291 (1955), citada por JAIRO Parra-Quijano, Manual de derecho probatorio, $426\left(10^{\mathrm{a}}\right.$ ed., Ediciones Librería del Profesional, Bogotá, 1999).

91 Una situación excepcional se dio en el caso Intersystem, pues los integrantes del acuerdo aceptaron la comisión de la conducta.

92 Sobre este tema, resoluciones 1055 de 2009, 64400 de 2011 y 53914 de 2013 de la Superinten- 
Así mismo, se ha encontrado que, empero la gran cantidad de intermediarios de seguros que hay, se emplea la misma empresa ${ }^{93}$, con pólizas contratadas el mismo día, con minutos de diferencia y un mismo número de cuenta del cual se origina el pago, entre otras $^{94}$; e igual ocurre en la entrega de la oferta, pues se presentan con segundos de diferencia, por la misma persona; entre otros muchos indicios que apuntan a señalar que efectivamente las empresas oferentes hacen parte de un acuerdo colusorio.

No obstante, repetimos, se trata de meros indicios que por sí solos no pueden probar la existencia del acuerdo, por lo que la autoridad de competencia se ve obligada a encaminar todos sus esfuerzos a demostrar que no hay otras consideraciones económicamente objetivas que puedan explicar este comportamiento, más allá de la existencia de un acuerdo entre los oferentes.

\section{ALGUNAS MEDIDAS QUE HAN IMPLEMENTADO LOS ESTADOS PARA HACER FRENTE A LA COLUSIÓN EN LOS PROCESOS DE SELECCIÓN DE CONTRATISTAS}

Es posible que el propio desarrollo del proceso contractual estimule la consolidación de acuerdos restrictivos de la competencia, circunstancia que plantea la pregunta sobre cómo lograr una competencia efectiva en los procesos de selección. La respuesta a este interrogante, como veremos, parece apuntar hacia la necesidad de promover la participación de un mayor número de oferentes en el proceso contractual, esto es, promover la competencia dentro del mismo.

dencia de Industria y Comercio.

93 Esto, por ejemplo, ocurrió en el caso IDIPRON, pues la Superintendencia pudo constatar que dos proponentes obtuvieron su póliza del mismo intermediario, con el agravante de que se encontraron correos electrónicos en los que uno de los proponentes le solicitaba al intermediario de seguros la expedición de pólizas no consecutivas para este y para otro proponente. En opinión de la Superintendencia: "Bien es sabido que la expedición consecutiva de pólizas de seguros a competidores en un proceso de contratación pública constituye una prueba importante en aquellos procesos en que se investiga la existencia de una presunta colusión, por lo cual las conductas encaminadas a ocultar dicha situación son un fuerte indicativo de que existió un acuerdo encaminado a afectar la competencia”. Superintendencia de Industria y Comercio, Resolución 53914 de 2013, 35.

94 Superintendencia de Industria y Comercio, Resolución 64400 de 2011. 
En efecto, un incremento de los oferentes puede hacer mucho más difícil la consolidación de acuerdos colusorios, pero para lograrlo se requerirá que las entidades encargadas de los procesos de selección adopten medidas que les faciliten la entrada ${ }^{95}$, al eliminar las barreras artificiales que puedan evitar su acceso.

Ahora bien, entre las medidas que entidades como la Organización para la Cooperación y el Desarrollo Económicos, $\mathrm{OCDE}^{96}$, han planteado para lograr una competencia efectiva es posible evidenciar, entre otras, aquellas que apuntan a la reducción de los costos de presentación de ofertas, el establecimiento de requisitos de participación que no limiten injustificadamente la competencia, tener flexibilidad con respecto al número de empresas de las que se requiere una oferta, el fomento a la presentación de ofertas por parte de empresas extranjeras, así como la búsqueda de formas para motivar la participación de compañías pequeñas.

En este mismo sentido, se ha recalcado la importancia de que el establecimiento de los requisitos de participación de los oferentes y de los criterios o factores de evaluación o calificación de sus ofertas, estén exentos de consideraciones subjetivas o de la imposición de factores formales o superfluos, pues los mismos suponen restricciones innecesarias que no propician una competencia sana y efectiva en el proceso contractual, ni garantizan la elección de la oferta más favorable a los intereses de la entidad, esto es, aquella que cumpla en mayor medida la finalidad del proceso de selección, que no es otro que el de alcanzar los fines estatales, la continua y eficiente prestación de los servicios públicos, y la efectividad de los derechos e intereses de los administrados ${ }^{97}$.

95 Nos referimos a oferentes adecuados, es decir, no cualquier oferente, sino aquel que realmente tenga la capacidad de propiciar un juego competitivo en el proceso contractual.

$96 \mathrm{La}$ OCDE ha creado una lista de verificación para el diseño de un proceso de adquisición que reduzca los riesgos de colusión en la presentación de ofertas. En ese sentido, ha establecido seis medidas fundamentales para lograrlo: 1) Contar con información adecuada antes de diseñar el proceso de licitación. 2) Diseñar el proceso de licitación para maximizar la participación potencial de licitadores que compiten genuinamente. 3) Definir los requisitos con claridad y evitar las medidas predecibles. 4) Diseñar el proceso de licitación para reducir eficazmente la comunicación entre oferentes. 5) Elegir con cuidado los criterios para evaluar y adjudicar la oferta. 6) Crear conciencia entre su personal acerca de los riesgos de la colusión en los procesos de adquisición. Organización para la Cooperación y el Desarrollo Económicos, OCDE, Lineamientos para combatir la colusión entre oferentes en licitaciones públicas, 5-13 (febrero de 2009). Disponible en: www.oecd.org, http://www.oecd.org/daf/competition/cartels/42761715. pdf

97 Artículo 3 de la Ley 80 de 1993. 
Así mismo, se considera que un acuerdo colusorio se verá facilitado si los competidores tienen la posibilidad de identificar a las demás empresas participantes, pues así les será más fácil acercarse a ellas a fin de plantear un posible acuerdo; de esta manera, la labor de las entidades contratantes deberá encaminarse a lograr un cierto grado de incertidumbre acerca de quiénes serán los participantes, a fin de entorpecer la comunicación ${ }^{98}$. Sin embargo, esto no será tan fácil en mercados especializados en donde los oferentes casi siempre son los mismos y en donde, incluso, en el pasado, han conformado uniones temporales o consorcios - lo cual resulta frecuente en la práctica-, o en mercados altamente sensibles.

Ahora, cuando quiera que a pesar de todas las medidas que se tomen en el proceso contractual, los agentes recurran al acuerdo colusorio para lograr o por lo menos aumentar sus posibilidades de resultar adjudicatarios, será necesario acudir a la imposición de sanciones, pero no cualquier tipo de sanción sino unas de tal magnitud que desestimulen el perfeccionamiento de esta clase de acuerdos ${ }^{99}$.

Este fue precisamente uno de los objetivos trazados por la Ley 1340 de 2009, que en el caso colombiano incrementó significativamente el monto de las multas que contemplaba el Decreto 2153 de 1992. En efecto, en vigencia del Decreto, las multas que se podían imponer a las personas jurídicas no sobrepasaban el tope de los 2.000 SMLMV y, en el caso de las personas naturales, las multas no superaban los $300 \mathrm{SMLMV}^{100}$. Hoy con las modificaciones

98 "Las comunicaciones entre competidores deben reducirse al mínimo. Las políticas de contratación pueden prever enérgicas medidas para desalentar las comunicaciones indebidas. Una de ellas es, por ejemplo, solicitar una declaración formal de licitación independiente y una declaración de las comunicaciones que hayan podido tener lugar. (...) Estas medidas encaminadas a disuadir el establecimiento de comunicaciones indebidas serán eficaces si las sanciones impuestas son severas y si las autoridades de la competencia se manifiestan especialmente interesadas en la detección de las infracciones". Organización de las Naciones Unidas, ONU, La política de la competencia y las adquisiciones del sector público, 14 (Conferencia de las Naciones Unidas sobre Comercio y Desarrollo, Junta de Comercio y Desarrollo, Comisión de Comercio y Desarrollo, Grupo Intergubernamental de Expertos en Derecho y Política de la Competencia, 12 período de sesiones, Ginebra, 9 a 11 de julio de 2012). Disponible en: http:// unctad.org/meetings/es/SessionalDocuments/ciclpd14_sp.pdf

99 En el proyecto de ley 038 de 2015 incluso se introduce una nueva causal de inhabilidad para contratar con el Estado, para quienes infrinjan normas sobre protección de la competencia en el marco de un proceso de contratación estatal, por un término de 6 meses a tres años (artículo 5 del proyecto que modifica el numeral 15 del artículo 4 del Decreto 2153 de 1992). Hoy, esta sanción de inhabilidad se contempla pero cuando se imponga una sanción penal.

100 Muestra de ello es que en el caso Intersystem las multas impuestas no superaron los 5 SMLMV, 
introducidas por el artículo 25 de la Ley 1340 de 2009, se pueden aplicar multas de hasta 100.000 SMLMV a las personas jurídicas o, si resultare mayor, hasta por el $150 \%$ de la utilidad derivada de la conducta por parte del infractor y, en caso de tratarse de una persona natural, es posible asignar multas de hasta de 2.000 SMLMV ${ }^{101}$. Así mismo, se pueden imputar multas por cada violación y a cada infractor por la contravención de cualquiera de las disposiciones sobre protección de la competencia, incluidas la omisión en acatar en debida forma las solicitudes de información, órdenes e instrucciones que imparta; la obstrucción de las investigaciones; el incumplimiento de las obligaciones de informar una operación de integración empresarial o las derivadas de su aprobación bajo condiciones o de la terminación de una investigación por aceptación de garantías. En vigencia de la norma anterior, solamente era posible imponer multas por violación a las normas sobre promoción de la competencia y prácticas comerciales restrictivas; en el caso del incumplimiento de instrucciones, si bien se establecía en el numeral 2 del artículo 2 del Decreto 2153 de 1992 (hoy derogado por el artículo 19 del Decreto 3523 de 2009) ${ }^{102}$ la facultad del superintendente para imponer sanciones por el no acatamiento de las instrucciones o por ejemplo, por no permitir la realización de visitas administrativas (lo que en la práctica resulta más común de lo debido), no se contemplaba el monto de la multa, lo que en ocasiones convertía la norma en letra muerta ${ }^{103}$.

bajo el argumento de que el monto de los contratos no superaba los 20 SMLMV.

101 En el mencionado proyecto de Ley 038 de 2015, se introducen unos criterios que la Superintendencia podrá utilizar para fijar la multa y establecer que deberá emplearse aquel cuyo tope sancionatorio resultare mayor. Entre ellos se establecen en el artículo 5 del proyecto: a) ingresos operacionales del infractor, b) el patrimonio del infractor, c) las ventas del infractor en relación con los productos o servicios sobre los que recayó el acuerdo anticompetitivo, d) un monto en salarios mínimos legales mensuales vigentes a cargo del infractor, que al igual a lo que sucede actualmente, no puede exceder de 100.000 SMLMV, e) el valor del contrato estatal en los casos de prácticas comerciales restrictivas que afecten o puedan afectar procesos de contratación pública, la cual no puede exceder el 30\% del valor del contrato, lo que resulta una modificación al régimen que actualmente opera y que muestra un incesante interés del legislador en castigar duramente esta clase de conductas. Así mismo, se modifica lo concerniente al porcentaje de la utilidad y lo sitúa en el $300 \%$ de la misma, cuando puedan cuantificarse las utilidades percibidas por el infractor derivadas de la conducta.

102 Colombia, Decreto 3523 de 2009, por el cual se modifica la estructura de la Superintendencia de Industria y Comercio y se determinan las funciones de sus dependencias, 47.473 Diario Oficial, 15 de septiembre de 2009. Disponible en: http://www.sic.gov.co/recursos_user/ documentos/normatividad/Decreto_3523_2009.pdf

103 Hoy se trata de una norma en todo su vigor, que ha sido utilizada por la Superintendencia para imponer sanciones por obstrucción a la investigación. Muestra de ello lo vemos por ejemplo 
No obstante lo anterior, si bien la imposición de sanciones administrativas puede ser un mecanismo que contribuya en el objetivo de evitar la consolidación de acuerdos restrictivos de la competencia, por sí solas no resultan suficientes para detenerlos, lo cual se explica en la medida en que se trata de una solución que está atada a la efectividad de la autoridad de competencia en la detección y sanción de esta clase de infracciones. En efecto, solo si los infractores avizoran que las sanciones que podrían imponerles ${ }^{104}$ son significativamente mayores a los beneficios que la consolidación de esta clase de acuerdo puede reportarles, y que la autoridad de competencia es eficaz tanto en su detección ${ }^{105}$ como en la imposición de sanciones administrativas, se logrará desestimular el perfeccionamiento de esta clase de acuerdos; de otra manera, será una tarea casi imposible.

Por todo lo anterior, consideramos que las medidas que deben desplegar las autoridades de competencia para luchar contra la colusión - y en general contra cualquier práctica restrictiva de la competencia - y mejorar la eficiencia en la contratación pública, deben acompañarse de un fortalecimiento de las labores de detección y prevención de estas conductas ${ }^{106}$.

en el caso de las empresas de seguridad y vigilancia, en donde mediante las resoluciones Nos. 11959 y 11963 de 2015, se confirmaron las sanciones impuestas a las empresas Cobasec y Starcoop por impedir que la Superintendencia tuviera acceso a la información que reposaba en computadores y correos electrónicos de las empresas, las multas ascendieron a la suma de \$2.439.360.000. Así mismo, en el caso de 11 embotelladoras de aceites vegetales comestibles, se impusieron sanciones por obstrucción la práctica de algunas visitas administrativas de inspección realizadas por la Superindustria.

104 Nos referimos al monto de las multas que impone por ejemplo la SIC, y a otros costos, como las costas judiciales, la negativa percepción pública que se obtiene, la inhabilitación, además de las posibles sanciones penales a las que se pueden ver abocados, entre otros costos, los cuales deberán ser valorados por las empresas al momento de decidir si participan o no en el acuerdo. Entre mayor sea el costo que deberán asumir los empresarios en caso de ser descubiertos, en mayor medida se desestimula la comisión de la conducta,

105 "Si se cree en la capacidad de las autoridades para detectar los casos de manipulación de licitaciones, los programas de indulgencia cobrarán importancia, lo que a su vez reforzará entre las empresas, la impresión de que es probable que los casos de manipulación de licitaciones sean detectados y enjuiciados". Organización de las Naciones Unidas, ONU, La política de la competencia y las adquisiciones del sector público, 21 (Conferencia de las Naciones Unidas sobre Comercio y Desarrollo, Junta de Comercio y Desarrollo, Comisión de Comercio y Desarrollo, Grupo Intergubernamental de Expertos en Derecho y Política de la Competencia, 12 período de sesiones, Ginebra, 9 a 11 de julio de 2012). Disponible en: http://unctad.org/ meetings/es/SessionalDocuments/ciclpd14_sp.pdf

106 En el caso colombiano, según el Informe Nacional de Competitividad 2013-2014, “(...) La Delegatura de Protección de la Competencia atendió un promedio de 29,5 casos en materia de colusión en licitaciones públicas entre 2011 y 2012, lo que representa un incremento de $1.538 \%$ con respecto al número promedio de casos atendidos entre 2000 y 2010 (1,8 caso por año) 
Precisamente, las actuales políticas de competencia trabajan en esta dirección con mayor fuerza, para evitar los efectos adversos que esta clase de comportamientos contrarios a la competencia puede tener en el mercado. Las ya mencionadas directrices de la $\mathrm{OCDE}^{107}$ incorporan una lista de verificación para detectar estos comportamientos, encaminada a ayudar a que las entidades contratantes puedan detectar indicios y señales de manipulación del proceso contractual, que se centra en los siguientes elementos: i) patrones y señales de advertencia en la presentación de las ofertas; ii) señales de advertencia en todos los documentos entregados; iii) patrones y señales de advertencia en los precios; iv) afirmaciones sospechosas; v) conductas sospechosas.

Sin duda, resulta necesario fortalecer la capacitación de los funcionarios encargados de la contratación en las entidades ${ }^{108}$, tanto del

(Robledo, 2013). Para finales de 2012, esta Delegatura investigaba más de 23 casos relacionados con más de 150 contratos, por un valor superior a $\$ 1,5$ billones. A la fecha de publicación de este informe, se han decidido varios casos en los que se comprobó colusión en contratos por valor de $\$ 100.000$ millones y, en lo corrido de 2013 se han impuesto sanciones por más de $\$ 34.000$ millones por prácticas anticompetitivas a través de colusiones en licitaciones. Estos resultados ayudarán a que más empresarios participen como proponentes en licitaciones públicas, pues se modifica la percepción de que la competencia en estos procesos no es justa (Robledo, 2013). Con el fin de prevenir colusiones en las licitaciones públicas, la SIC diseñó una aplicación para que las entidades públicas puedan identificar potenciales riesgos de colusión en estos procesos". Colombia, Consejo Privado de Competitividad, Informe Nacional de Competitividad 2013-2014, Capítulo diez, Promoción y Protección de la Competencia, 174175 (Consejo Privado de Competitividad, Bogotá, 2013). Disponible en: http://www.compite. com.co/site/wp-content/uploads/2013/11/CPC_INC2013-2014-Informe.pdf. Igualmente, cabe destacar que la SIC fue aceptada en condición de observador en el Comité de Competencia de la OCDE. Ahora bien, en el tema de colusión, debe resaltarse que, en abril de 2012, la SIC conformó un Grupo Interdisciplinario de Colusiones, con el fin de mejorar el seguimiento a los procesos de contratación estatal. Si bien son logros que deben destacarse, consideramos que resta mucho por hacer, aún hay un número muy alto de acuerdos colusorios en los procesos de contratación - tanto pública como privada-, que no se ha detectado y sancionado, por eso debe ser un trabajo conjunto entre la autoridad de la competencia, los ordenadores del gasto y los organismos de fiscalización.

107 Organización para la Cooperación y el Desarrollo Económicos, OCDE, Lineamientos para combatir la colusión entre oferentes en licitaciones públicas, $14-17$ (febrero de 2009). Disponible en: www.oecd.org, http://www.oecd.org/daf/competition/cartels/42761715.pdf

108 Sobre este particular, la OCDE resalta la importancia de la capacitación para "fortalecer la conciencia de los funcionarios a cargo de las adquisiciones sobre temas de competencia en este sector. Los esfuerzos para combatir la colusión más eficazmente pueden apoyarse por medio de la recolección de información histórica sobre conductas en licitaciones, dando seguimiento constante a las actividades de presentación de ofertas y realizando análisis acerca de los datos relacionados con las ofertas. Esto ayuda a que los organismos encargados de las adquisiciones (y las autoridades de competencia) identifiquen situaciones problemáticas. Cabe destacar que la colusión en los procesos de adquisición puede no ser evidente a partir de los resultados de una sola oferta. A menudo, los esquemas de colusión solo se revelan cuando se analizan los resultados de una serie de ofertas en un período dado". Organización para la Cooperación y el Desarrollo Económicos, OCDE, Lineamientos para combatir la colusión 
sector público como del privado, pues - al estar al frente del proceso contractual - tienen mayores posibilidades de detectar una posible manipulación. No hay autoridad de competencia en el mundo con la capacidad de revisar todos los procesos contractuales que día a día se inician. Por ello resulta vital una colaboración eficaz entre estas y los funcionarios encargados de la contratación. Pero para que esta labor de colaboración resulte fructífera "es fundamental llegar a un claro entendimiento común sobre las señales que se deben tener en cuenta, sobre la forma de documentar los presuntos casos de manipulación de licitaciones y sobre la colaboración e información que puede ser necesaria una vez remitido el caso a una autoridad de competencia"109.

Resulta necesario extender esta labor a otras autoridades competentes para combatir la corrupción en los procesos contractuales - en nuestro país, Procuraduría, Contraloría, Fiscalía, Zar anticorrupción, entre otros - y también a los propios empresarios - pues en muchos casos ellos incurren en estas prácticas por desconocimiento de las normas ${ }^{110}$ _ e incluso, extender la labor de capacitación y educación a las instituciones educativas ${ }^{111}$.

A la par de las medidas que pueden adoptar tanto las entidades contratantes como las autoridades de competencia en los procesos de selección, llama la atención otra clase de herramientas que los

entre oferentes en licitaciones públicas, 11-12 (febrero de 2009). Disponible en: www.oecd.org, http://www.oecd.org/daf/competition/cartels/42761715.pdf. En el caso colombiano, la SIC ha avanzado en este tema a través de una serie de "Talleres sobre cómo combatir la colusión entre oferentes en licitaciones públicas", en cooperación con la OCDE, en la ciudad de Bogotá; sin embargo queda mucho camino por recorrer, pues se requiere que esta labor se repita en todo el país.

109 Organización de las Naciones Unidas, ONU, La politica de la competencia y las adquisiciones del sector público, 17 (Conferencia de las Naciones Unidas sobre Comercio y Desarrollo, Junta de Comercio y Desarrollo, Comisión de Comercio y Desarrollo, Grupo Intergubernamental de Expertos en Derecho y Política de la Competencia, 12 período de sesiones, Ginebra, 9 a 11 de julio de 2012). Disponible en: http://unctad.org/meetings/es/SessionalDocuments/ ciclpd14_sp.pdf

110 Por ejemplo, en el caso Intersystem, los investigados reconocieron la comisión de la conducta; sin embargo, se excusaron en el hecho de que no creían estar haciendo nada contrario a la Ley. En efecto, en el escrito de observaciones al Informe Motivado, las partes manifestaron: "Efectivamente sí existió acuerdo entre los tres (3) investigados, es más, nunca se negó. Ahora bien, que a ese acuerdo se da el tinte de acto doloso, de mala fe, torticero y/o con fines de dañar a uno o unos terceros ello no es cierto". Superintendencia de Industria y Comercio, Resolución 1055 de 2009, 2.

111 A propósito de este tema, el Estatuto Anticorrupción estableció en sus artículos 79 y 80 la obligación de realizar campañas educativas sobre el tema de la corrupción, y sería interesante replicarlo en materia de colusión y en general, sobre las prácticas que restringen la competencia. 
Estados han implementado para combatir la colusión, unas quizás más exitosas que otras, pero todas igualmente significativas. Nos referimos a la penalización de la conducta, la utilización de los programas de clemencia y la elaboración de guías y cartillas, entre otras.

En Colombia, por ejemplo, uno de los instrumentos que se han esgrimido en los últimos años para combatir el creciente flagelo de la corrupción es el denominado Estatuto Anticorrupción ${ }^{112}$, que en su artículo 27 (que incluye el artículo 410A del Código Penal) ${ }^{113}$ establece el delito de "acuerdos restrictivos de la competencia". Se trata de una norma muy particular que creó un antecedente importantísimo en la materia, en la medida en que penalizó los acuerdos restrictivos que se presenten en los procesos de licitación pública, subasta pública, selección abreviada o concurso, con penas de prisión de 6 a 12 años y multa de 200 a 1.000 smlmv e inhabilidad para contratar con entidades estatales por 8 años $^{114}$ - a la par de las sanciones administrativas que ya reseñamos—-, lo cual sin duda denota la importancia del tema, en especial a partir de las investigaciones que se han realizado con ocasión del denominado carrusel de la contratación ${ }^{115}$. Con esta medida, se evidencia que el gobierno

112 Colombia, Ley 1474 de 2011, por la cual se dictan normas orientadas a fortalecer los mecanismos de prevención, investigación y sanción de actos de corrupción y la efectividad del control de la gestión pública, Estatuto Anticorrupción, 48.128 Diario Oficial, 12 de julio de 2011. Disponible en: http://www.secretariasenado.gov.co/senado/basedoc/ley_1474_2011.html

113 Colombia, Ley 599 de 2000, por la cual se expide el Código Penal, 44.097 Diario Oficial, 24 de julio de 2000. Disponible en: http://www.secretariasenado.gov.co/senado/basedoc/ ley_0599_2000.html

114 En el proyecto de ley No. 038 de 2015, se introducen cambios importantes a este artículo al sancionar no solamente los acuerdos colusorios en procesos de licitación pública, subasta pública, selección abreviada o concurso, sino cualquier "proceso de contratación pública". Así mismo, se contempla el ejercicio de la acción penal por la Superintendencia de Industria y Comercio. En efecto el artículo 11 del proyecto establece: "Artículo 11. Ejercicio de la acción penal por la Superintendencia de Industria y Comercio. Atendiendo al bien jurídico tutelado, y a la condición de Autoridad Nacional de Protección de la Competencia en Colombia, de conformidad con lo establecido en el parágrafo 2 del artículo 250 de la Constitución Política, la Superintendencia de Industria y Comercio podrá ejercer la acción penal respecto del delito de Acuerdos Restrictivos de la Competencia, contemplado en el artículo 410 A de la Ley 599 de 2000. Lo anterior sin perjuicio del poder preferente que sobre el ejercicio de la acción penal tiene la Fiscalía General de la Nación".

115 El Carrusel de la Contratación fue el nombre con que los medios de comunicación identificaron un escándalo de corrupción que se suscitó en la ciudad de Bogotá en 2010 y en el que resultaron involucrados tanto el Alcalde de esa época, Samuel Moreno, algunos integrantes del Concejo de Bogotá, funcionarios del Distrito, contratistas, y el hermano del exalcalde, el congresista Iván Moreno. El escándalo estalló el 25 de junio de 2010, cuando un medio de comunicación reveló algunos audios que involucraban al contralor de Bogotá de la época, Germán Olano, con Miguel Nule, uno de los mayores contratistas del Distrito y quien tenía 
colombiano ha tomado conciencia de la gravedad de esta clase de acuerdos, pues no solamente limitan la libre competencia que debe imperar en el mercado sino que constituyen una agresión directa al patrimonio económico del Estado y vulneran los principios que deben regir la contratación estatal.

Sin embargo, la experiencia nacional e internacional ha demostrado que la penalización y sanción por parte de las autoridades no resulta suficiente para contener la proliferación de acuerdos colusorios; por el contrario, se ha traducido en una sofisticación de la figura, de modo que para las autoridades cada día se hace mucho más difícil el desvelamiento de los carteles; en esa medida, se ha migrado hacia otros instrumentos que permitan que los mismos participantes del acuerdo sean los primeros colaboradores de la justicia; de ahí la importancia que han cobrado los programas de clemencia, también llamados programas de amnistía o política de inmunidad corporativa. En el caso colombiano, esta figura se introdujo con la expedición de la Ley 1340 de 2009, que en su artículo 14 le otorgó la facultad a la Superintendencia de Industria y Comercio para conceder beneficios a las personas naturales o jurídicas que hubieren participado en una conducta restrictiva de la competencia, por colaborar en la entrega de información o pruebas, y en la identificación de los demás participantes ${ }^{116}$, programa a su vez reglamentado por el Decreto 1523 de 2015.

a su cargo la construcción de la fase III de Transmilenio en la Calle 26; según los audios, presuntamente se estaban negociando comisiones con contratistas. A los pocos días, se anunciaron investigaciones por parte de la Fiscalía, la Procuraduría y la Corte Suprema de Justicia, a las que se unieron las denuncias de una comisión del Polo Democrático, liderada por el entonces senador, Gustavo Petro, que denunció una presunta participación del Alcalde de la ciudad y de su hermano en la exigencia de comisiones a los contratistas para la adjudicación de contratos. Este escándalo llevó a la destitución del Alcalde por la Procuraduría y a una serie de investigaciones penales contra los involucrados por los delitos de celebración de contratos sin el lleno de los requisitos legales, concierto para delinquir, peculado por apropiación, cohecho propio, concusión, prevaricato por omisión, tráfico de influencias e interés indebido en la celebración de contratos, entre otros. En la actualidad, el exalcalde Samuel Moreno fue condenado por el Juez 14 de Conocimiento y enfrenta una pena de hasta 24 años de cárcel, siendo apenas el primero de los tres procesos en su contra.

116 En armonía con las medidas de clemencia establecidas por la Ley 1340 de 2009, el parágrafo del artículo 410A del Código Penal (artículo 27 del Estatuto Anticorrupción) establece la posibilidad de una reducción de la pena privativa de la libertad en una tercera parte, una rebaja del $40 \%$ de la multa a imponer y una inhabilidad para contratar con entidades estatales por cinco años, para aquellos que hayan accedido al programa de clemencia y hayan obtenido una exoneración total de la sanción. Ahora, con la aprobación del Proyecto de ley 038 de 2015, se aplicaría el principio de oportunidad en caso de obtenerse una exoneración total de la sanción administrativa. El artículo en mención establece: "Artículo 14. Modifíquese el artículo 410A de 
Finalmente, otro instrumento que vale la pena mencionar es la proliferación de guías o cartillas, que si bien no constituyen reglas o normas de estricto cumplimiento, sino meras recomendaciones de comportamiento que deberían seguir tanto los competidores como las propias instituciones, sí constituyen un instrumento valioso en la tarea de capacitación a los distintos agentes del mercado, autoridades de competencia y órganos de control. En el caso colombiano, la Superintendencia de Industria y Comercio de Colombia, con el auspicio de la Unión Europea ${ }^{117}$, expidió en diciembre de 2010 la Guía práctica para combatir la colusión en las licitaciones ${ }^{118}$, que tiene como objeto suministrar, tanto a los funcionarios públicos como a los particulares, algunos elementos que les permitan identificar, en los procesos de contratación pública, la ocurrencia de acuerdos colusivos, y coadyuvar al inicio de investigaciones administrativas correspondientes, evitando con ello la ocurrencia de actos de corrupción y fraude en estos procesos.

la Ley 599 de 2000, el cual quedará así: Artículo 410A. Acuerdos restrictivos de la competencia en procesos de contratación pública. El que en un proceso de contratación pública se concertare con otro con el objeto de restringir, limitar o eliminar la competencia, incurrirá en prisión de seis (6) a doce (12) años y multa de doscientos (200) a mil (1.000) salarios mínimos legales mensuales vigentes e inhabilidad para contratar con entidades estatales por ocho (8) años. Parágrafo. La Fiscalía General de la Nación otorgará el principio de oportunidad a quien dentro de la investigación administrativa adelantada por la Superintendencia de Industria y Comercio haya obtenido la exoneración total de la multa a imponer mediante resolución en firme, en virtud de la suscripción de un acuerdo de beneficios por colaboración, siempre que cumpla con lo previsto en los numerales 5 o 6 del artículo 324 de la Ley 906 de 2004".

117 Proyecto Asistencia Técnica al Comercio para Colombia.

118 Superintendencia de Industria y Comercio de Colombia, Unión Europea, Guía práctica para combatir la colusión en las licitaciones (Superintendencia de Industria y Comercio de Colombia, Unión Europea, Delegación de la Unión Europea en Colombia, Bogotá, 2010). Disponible en: https://issuu.com/asteroide10/docs/cartilla_colusiones_vf_para_publica 


\section{CONCLUSIONES}

Sin duda, los Estados se han convertido en uno de los mayores consumidores de bienes y servicios. Por esto, las conductas tendientes a manipular los procesos contractuales constituyen una de las más graves lesiones a la libre competencia. De esta manera, la labor que deben emprender las autoridades de competencia, los órganos de control y la propia ciudadanía, a fin de repeler la consolidación de acuerdos colusorios, resulta esencial en la lucha contra este flagelo.

La colusión en los procesos de selección de contratistas falsea la competencia y lleva a la Administración a escoger al proponente impuesto por este juego anticompetitivo, que la mayoría de las veces resulta el oferente menos apto y el más dispuesto a generar sobrecostos en el contrato, para poder atender las retribuciones económicas pactadas con los demás participantes del acuerdo colusorio.

Por ello, no puede concebirse un escenario de libre competencia, en el cual la adjudicación de un contrato no sea el resultado de una pugna entre los proponentes, sino de una maniobra fraudulenta, en la que mediante un acuerdo anticompetitivo los coludidos aumentan sus posibilidades de resultar seleccionados. Se afectan así, tanto el mercado, los intereses particulares de quienes buscan resultar adjudicatarios por medios legales y en franca competencia, como el interés general manifestado tanto en un detrimento patrimonial para el Estado como en una indebida restricción a la competencia.

En ese orden de ideas, resulta destacable la labor que ha emprendido la Superintendencia de Industria y Comercio en la detección de esta clase de acuerdos colusorios; sin embargo, queda mucho camino por recorrer, en especial porque la labor de esta entidad se ha concentrado en los procesos contractuales que lleva a cabo el Estado bajo los parámetros del Estatuto General de Contratación Estatal y ha olvidado que estas conductas también se pueden desarrollar en el ámbito privado y en el de aquellas entidades que por expresa disposición escapan de esta regulación, aunque el contenido del numeral 9 del artículo 47 del Decreto 2153 de 1992 no los excluye.

Ahora bien, de la postura de la Superintendencia, sí consideramos criticable su interpretación del numeral 9 del artículo 47 del Decreto 2153 de 1992, en el sentido de extender la aplicación del descriptivo normativo positivo, a aquellos procesos de selección 
diferentes a la licitación o concurso cuando quiera que la conducta tiene "por objeto" la colusión; lo cual contraviene los principios que gobiernan el derecho administrativo sancionador, como ya examinamos en extenso en apartados anteriores. A nuestro juicio, se trata de una posición que conlleva un gran riesgo jurídico para la entidad y que a su vez crea un estado de inseguridad jurídica para los agentes del mercado y para la ciudadanía en general.

En consonancia con lo anterior, creemos indispensable una revisión y actualización del numeral 9 del artículo 47 del Decreto 2153 de 1992, pues se concibió bajo la vigencia de normas en materia de contratación estatal que han sido derogadas, de modo que si se desea perseguir esta conducta de manera integral, es menester adecuar la norma a este querer y establecer los elementos del binomio infracción-sanción que componen la conducta colusoria en cualquier modalidad de selección, con lo cual se evita el perfeccionamiento de los riesgos antes mencionados.

Por ello, si bien las sanciones a imponer deben ser drásticas, también resulta indispensable fortalecer otros mecanismos de coerción y colaboración con la autoridad de competencia. En este sentido, los programas de clemencia pueden resultar un mecanismo interesante, pero para ello, por lo menos en el caso colombiano, será necesario no solamente que la Superintendencia realice mayores esfuerzos por dar a conocer esta figura, sino que resulta urgente modificar el régimen previsto en el actual Estatuto Anticorrupción, en el que al tratarse de acuerdos colusorios establece una sanción penal al comportamiento y solamente una reducción en el caso en que el clemente logre la exoneración total de la sanción administrativa aplicable.

En consonancia con lo anterior, consideramos importante que se le permita una exoneración total tanto de la sanción penal como de la multa e inhabilidad aplicable, al delator que colabore eficazmente en el desvelamiento de un acuerdo colusivo, por lo menos en aquellos eventos en que la Superintendencia de Industria y Comercio no tenga noticia de la existencia del acuerdo. De otra manera, el mecanismo continuará sin dar los resultados esperados, como hasta la fecha parece haber sucedido; el hecho de que desde 2009 solo se tenga noticia de un caso exitoso de un colaborador en 
investigaciones por acuerdos colusorios ${ }^{119}$, permite deducir que la introducción de sanciones penales ha podido repercutir negativamente en la utilización de la figura ${ }^{120}$, mientras que la posibilidad de una sanción penal está desestimulando su utilización.

Precisamente, como respuesta a esta preocupación que hemos venido planteando desde la doctrina, el Proyecto de ley 038 de 2015 que cursa en el Congreso y que modificaría tanto la Ley 1340 de 2009 como lo concerniente al delito de Acuerdos Restrictivos de la Competencia, contempla no solamente una exoneración total de la multa sino la aplicación del principio de oportunidad, lo cual hasta este momento ha sido objeto de discusión; esperemos una buena marcha de este proyecto de ley.

Finalmente, resulta también urgente y necesario que las autoridades de competencia fortalezcan las labores de prevención y detección y el trabajo coordinado entre estas, organismos de control y entidades contratantes, para ser mucho más eficaces en la lucha contra este flagelo, puesto que medidas que de manera independiente se han venido implementando no parecen estar siendo tan eficaces como se requiere.

119 Hasta 2015, en el caso Empresas de Vigilancia que ya hemos referenciado, se ha tenido noticia del ingreso de un delator al programa de beneficios por colaboración en una investigación por acuerdos colusorios. En este caso, aún no se ha emitido una decisión definitiva y por lo tanto no se ha podido saber si se le han otorgado al delator los beneficios que establece la ley por colaboración. Otros casos de clemencia se han dado en las investigaciones por los denominados carteles de los "pañales" y del "papel higiénico", pero no han sido conductas investigadas por colusión sino por acuerdos de precios.

120 Esta misma opinión tiene el Consejo Privado de Competitividad que en su Informe Nacional de Competitividad 2013-2014 al respecto señala: "Esta normativa tiene un efecto negativo puesto que ninguna persona natural se atreverá a delatar un cartel de contratación pública si por esto queda expuesta a una pena de prisión. Dado que la experiencia internacional muestra que una política efectiva de delación es fundamental para combatir los acuerdos colusivos, esta provisión dificulta seriamente la detección y la sanción de este tipo de prácticas en licitaciones públicas en el país". Colombia, Consejo Privado de Competitividad, Informe Nacional de Competitividad 2013-2014, Capítulo diez, Promoción y Protección de la Competencia, 173 (Consejo Privado de Competitividad, Bogotá, 2013). Disponible en: http://www.compite.com. co/site/wp-content/uploads/2013/11/CPC_INC2013-2014-Informe.pdf 


\section{BIBLIOGRAFÍA}

\section{Libros}

Arrowsmith, Sue, Treumer, Steen; Fejø, Jens \& Jiang, Lili, Public Procurement Regulation: An introduction (The EU Asia Inter University Network for Teaching and Research in Public Procurement Regulation, University of Nottingham, Nottingham, 2011). Disponible en: http://eprints.nottingham.ac.uk/1689/

Bassols-Coma, Martín, Constitución y sistema económico (Tecnos, Madrid, 1988)

Benavides, José Luis \& Santofimio, Jaime Orlando, comps., Contratación estatal. Estudios sobre la reforma del Estatuto Contractual. Ley 1150 de 2007 (Universidad Externado de Colombia, Bogotá, 2009).

Coloma, Germán, Defensa de la competencia. Análisis económico comparado (Ciudad Argentina, Buenos Aires, 2003).

Matallana-Camacho, Ernesto, Manual de Contratación de la Administración Pública ( $3^{\text {a }}$ edición, Universidad Externado de Colombia, Bogotá, 2013).

Parra-Quijano, Jairo, Manual de derecho probatorio (10 a ed., Ediciones Librería del Profesional, Bogotá, 1999).

Safar-Díaz, Mónica Sofía, Análisis económico de los procedimientos de selección de contratistas del Estado en el derecho colombiano: hacia un mecanismo eficiente $y$ transparente (Serie Derecho Administrativo 6, Universidad Externado de Colombia, Bogotá, 2009).

Velandia, Mauricio, Derecho de la competencia y del consumo (2 ${ }^{\mathrm{a}}$ ed., Universidad Externado de Colombia, Bogotá, 2011).

\section{Colaboración en obras colectivas}

Andrade-Castro, Jason Alexander, Aproximación a los nuevos tipos penales para combatir la corrupción, en XXXIV Jornadas Internacionales de Derecho Penal, Retos del Derecho Penal Contemporáneo: corrupción y seguridad ciudadana, 9-73 (Manuel Alberto Morales-Támara, Camilo Sanpedro-Arrubla, Paula Andrea Ramírez, Iván Machado-Rodríguez, Carlos Arturo Gómez-P., Carlos Diez Gómez-Jara, Percy García-Cavero, Ángela María Buitrago \& Jason Alexander Andrade-Castro, Universidad Externado de Colombia, Bogotá, 2012).

Cañizares, Enrique \& Domínguez, Daniel, Perspectiva económica de la colusión, en Los acuerdos horizontales entre empresas, 23-46 (SAntiago Martínez-LAge \& AMAdEO Petitbò-Juan, dirs., Fundación Rafael del Pino, Marcial Pons, Madrid, 2009).

Expósito-Vélez, Juan CARlos, El deber de selección objetiva, en Contratación estatal. Estudios sobre la reforma del estatuto contractual. Ley 1150 de 2007 (José LuIs Benavides \& Jaime Orlando Santofimio, comps., Universidad Externado de Colombia, Departamento de Derecho Administrativo, Bogotá, 2009).

Mehta, Pradeep Singh, La corrupción en la competencia de mercado: colusión y carteles, 
en Informe Global de la Corrupción 2009. Corrupción y sector privado, 29-35 (1 ${ }^{\mathrm{a}}$ pub., Dieter Zinnbauer, Rebecca Dobson \& Krina Despota, Transparency International, Ernst \& Young, eds., Cambridge University Press, Cambridge, 2009). Disponible en: http://issuu.com/transparencyinternational/docs/global_ corruption_report_2009_es/68

Rincón-Córdoba, Jorge Iván, Comentarios del capítulo Procedimiento Administrativo Sancionatorio, en Código de Procedimiento Administrativo y de lo Contencioso Administrativo, Ley 1437 de 2011, comentado y concordado, 142-151 (JosÉ LuIS Benavides, ed., Editorial Universidad Externado de Colombia, Bogotá, 2013).

Zárate-Pérez, Aníbal Rafael, Análisis económico por el juez de lo contencioso administrativo. Prácticas restrictivas de la competencia. Acuerdos de fijación de precios. Consejo de Estado, Sala de lo Contencioso Administrativo, Sección Primera, sentencia del 28 de enero del 2010, expediente ${ }^{\circ}$ 25000-23-24-000-200100364-01, en Los grandes fallos de la jurisprudencia administrativa colombiana, 410-418 (Andrés Fernando Ospina-Garzón, ed., Universidad Externado de Colombia, Bogotá, 2013).

\section{Revistas}

Archila-Peñalosa, Emilio José \& Pabón-Almanza, Camilo, Colusión en licitaciones $y$ concursos. El caso paradigmático para las entidades estatales, 38 Con-Texto, Revista de Derecho y Economía, 9-32 (Universidad Externado de Colombia, Bogotá, 2012). Disponible en: http://revistas.uexternado.edu.co/index.php/ contexto/article/view/3315/2965

Bendezú-Barnuevo, Rocci Fiorella, Análisis típico del delito de colusión y su tratamiento jurisprudencial, 1 IUS, Revista de Investigación Jurídica de la Facultad de Derecho, 1-32 (Universidad Católica Santo Toribio de Mogrovejo, Perú, enero- junio de 2011). Disponible en el sitio: www.usat.edu.pe

Berasategui, JAVIER, La integración de la contratación pública en la defensa de la competencia, 247 Gaceta Jurídica de la Unión Europea y de la Competencia, 35-52 (enero a febrero de 2007).

García-Gutiérrez, Grace, Protección de la competencia a través del derecho penal, 37 Con-Texto, Revista de Derecho y Economía, 37-52 (Universidad Externado de Colombia, Bogotá, 2012). Disponible en: http://revistas.uexternado.edu.co/index. $\mathrm{php} /$ contexto/article/view/3215/2864

Gutiérrez R., Juan David, El caso ANDEVIP [Asociación Nacional de Entidades de Seguridad Privada] (tercera entrega), Derecho y Política de Libre Competencia en América Latina (marzo de 2010). Disponible en: http://lalibrecompetencia. com/2010/03/17/el-caso-andevip-tercera-entrega/, http://lalibrecompetencia. com/2010/03/07/el-caso-andevip-segunda-entrega/, http://lalibrecompetencia. com/2010/03/05/el-caso-andevip-primera-entrega/

Mardas, Dimitri, Tendering Procedures and Buy-National Policies, 5 International Advances in Economic Research, 2, 189-203 (1999). Disponible en: http:// findarticles.com/p/articles/mi_hb3090/is_2_5/ai_n28738195/

Miranda-Londoño, Alfonso, Anotaciones sobre el Derecho Antimonopolístico en 
los Estados Unidos de Norteamérica, 11 Revista de Derecho Privado, 131-157 (Universidad de los Andes, Centro de Estudios de Derecho de la Competencia, CEDEC, Bogotá, diciembre de 1992). Disponible en: https://derechoprivado. uniandes.edu.co/components/com_revista/archivos/derechoprivado/pri356.pdf, https://centrocedec.files.wordpress.com/2010/06/anotaciones-sobre-derechoantimonopolistico-de-e-e-u-u-alfonso-miranda-londono.pdf

Molina-Gómez, Juliana, Hacia una implementación de un programa de clemencia en Colombia, 5 Revista de Derecho de la Competencia, 5, 609-657 (enero-diciembre, 2009). Disponible en: www.centrocedec.org. https://centrocedec.files.wordpress. com/2010/06/11-molina.pdf

Pascual-García, José, La huida del derecho administrativo, del presupuesto y de los controles financieros por los nuevos entes del sector público, 3 Revista Presupuesto y Gasto Público, Instituto de Estudios Fiscales, IEF, 109-128 (2010). Disponible en: http://www.ief.es, http://www.ief.es/documentos/recursos/publicaciones/revistas/ presu_gasto_publico/60_07.pdf

Serrano-Pinilla, Felipe, El derecho de la competencia como mecanismo para garantizar rivalidad en las licitaciones públicas e impulsar el crecimiento económico, 9 International Law, Revista Colombiana de Derecho Internacional, 19, 147-182 (julio-diciembre de 2011). Disponible en: http://revistas.javeriana.edu.co/index. php/internationallaw/article/view/13737/0

Tamayo-Álvarez, Rafael, Fundamentos económicos para la aplicación de las normas de libre competencia y el caso ANDEVIP y la existencia de prácticas restrictivas absolutas en Colombia, 6 Revista del Derecho de la Competencia, 6, 145-172 (enero-diciembre 2010). Disponible: www.javeriana.edu.co, https://centrocedec. files.wordpress.com/2010/06/4-tamayo-alvarez.pdf

Uribe-Gil, Jorge Mario \& Ulloa-Villegas, Inés María, Revisando la hipótesis de los mercados eficientes: nuevos datos, nuevas crisis y nuevas estimaciones, 30 Cuadernos de Economía, 55, 127-154 (2011), Disponible en: http://redalyc.org/ articulo.oa?id=282121963007, http://www.bdigital.unal.edu.co/29640/1/28227100352-1-PB.pdf

\section{Conferencias, ponencias, tesis}

Miranda-Londoño, Alfonso, El régimen general de la libre competencia: características principales (ponencia en el marco del Segundo Congreso Iberoamericano de Derecho Empresarial: Formas de control, competencia empresarial y propiedad industrial, Bogotá, octubre de 1997). Disponible en: https://centrocedec.files. wordpress.com/2011/07/1-rc3a9gimen-general-de-la-libre-competencia-aml.pdf

Ramírez-Duarte, Olga Lucía, Mecanismos para combatir la colusión en licitaciones: efectos de las decisiones sancionatorias sobre el proceso licitatorio en Colombia (trabajo de investigación presentado como requisito para optar al título de Magíster en Derecho Administrativo, Colegio Mayor de Nuestra Señora del Rosario, Bogotá, 2012). Disponible en: http://repository.urosario.edu.co/ handle/10336/3591

Ruiz-López, CARmen Eloísa, Colusión en licitaciones públicas desde la perspectiva del derecho de la competencia y el derecho penal (conferencia, Universidad Externado 
de Colombia, Bogotá, 30 de noviembre de 2011).

\section{Normatividad internacional}

Estados Unidos, Consolidated Antitrust Laws from the United States Code, 15 US Code $\S \S 1-7$ (Sherman Act); 15 US Code $\S \S 12-27$ and 29 US Code $\S \S 52-53$ (Clayton Act); 15 US Code $\$ \S 41-58$ (The Federal Trade Commission Act); 15 US Code $\S 13$ (Robinson-Patman Act). Disponible en: http://www.wipo.int/wipolex/en/ details.jsp?id=5408

Unión Europea, Directrices sobre la evaluación de las concentraciones horizontales con arreglo al Reglamento del Consejo sobre el control de las concentraciones entre empresas (2004/C 31/03), Diario Oficial de la Unión Europea, 9, 5 de febrero de 2004. Disponible en: http://eur-lex.europa.eu/legal-content/ES/ TXT/?uri=URISERV\%3A126107

Unión Europea, Reglamento (CE) 1/2003 del Consejo, de 16 de diciembre de 2002, relativo a la aplicación de las normas sobre competencia previstas en los artículos 81 y 82 del Tratado. Disponible en: http://eur-lex.europa.eu/legal-content/ES/ TXT/?uri=URISERV:126092

Unión Europea, Tratado de Funcionamiento de la Unión Europea, TFUE, C83 Diario Oficial de la Unión Europea, 30 de marzo de 2010. Disponible en: http://www. boe.es/doue/2010/083/Z00047-00199.pdf

\section{Normatividad colombiana}

Colombia, Constitución Política, segunda edición corregida, 116 Gaceta Constitucional, 20 de julio de 1991. Disponible en: http://www.secretariasenado.gov.co/senado/ basedoc/constitucion_politica_1991.html

Colombia, Decreto 222 de 1983, por el cual se expiden normas sobre contratos de la Nación y sus entidades descentralizadas y se dictan otras disposiciones. Disponible en: http://legislacion.vlex.com.co/vid/decreto-222-1983-expiden-589245879

Colombia, Decreto 2153 de 1992, por el cual se reestructura la Superintendencia de Industria y Comercio y se dictan otras disposiciones, 40.704 Diario Oficial, 31 de diciembre de 1992. Disponible en: http://www.secretariasenado.gov.co/senado/ basedoc/decreto_2153_1992.html

Colombia, Decreto 3523 de 2009, por el cual se modifica la estructura de la Superintendencia de Industria y Comercio y se determinan las funciones de sus dependencias, 47.473 Diario Oficial, 15 de septiembre de 2009. Disponible en: http://www.sic.gov.co/recursos_user/documentos/normatividad/ Decreto_3523_2009.pdf

Colombia, Decreto 2896 de 2010, por el cual se reglamenta el artículo 14 de la Ley 1340 de 2009, 47.792 Diario Oficial, 5 de agosto de 2010. Disponible en: http:// www.sic.gov.co/recursos_user/documentos/normatividad/Decretos/2010/ Deccreto_2896_2010.pdf

Colombia, Decreto 1082 de 2015, por medio del cual se expide el decreto único 
reglamentario del sector administrativo de planeación nacional, 26 de mayo de 2015. Disponible en: https://www.dnp.gov.co/Paginas/Normativa/Decreto1082-de-2015.aspx

Colombia, Ley 155 de 1959, por la cual se dictan algunas disposiciones sobre prácticas comerciales restrictivas, 30138 Diario Oficial, 22 de enero de 1960. http://www. alcaldiabogota.gov.co/sisjur/normas/Norma1.jsp?i=38169

Colombia, Ley 80 de 1993, por la cual se expide el Estatuto General de Contratación de la Administración Pública, 41.094 Diario Oficial, 28 de octubre de 1993. Disponible en: http://www.secretariasenado.gov.co/senado/basedoc/ley_0080_1993.html

Colombia, Ley 599 de 2000, por la cual se expide el Código Penal, 44.097 Diario Oficial, 24 de julio de 2000. Disponible en: http://www.secretariasenado.gov.co/senado/ basedoc/ley_0599_2000.html

Colombia, Ley 610 de 2000, por la cual se establece el trámite de los procesos de responsabilidad fiscal de competencia de las contralorías, 44.133 Diario Oficial, 18 de agosto de 2000. Disponible en: http://www.secretariasenado.gov.co/senado/ basedoc/ley_0610_2000.html

Colombia, Ley 734 de 2002, por la cual se expide el Código Disciplinario Único, 44.708 Diario Oficial, 13 de febrero de 2002. Disponible en: http://www.secretariasenado. gov.co/senado/basedoc/ley_0734_2002.html

Colombia, Ley 906 de 2004, por la cual se expide el Código de Procedimiento Penal, 45.658 Diario Oficial, 1 de septiembre de 2004. Disponible en: http://www. secretariasenado.gov.co/senado/basedoc/ley_0906_2004.html

Colombia, Ley 1150 de 2007, por medio de la cual se introducen medidas para la eficiencia y la transparencia en la Ley 80 de 1993 y se dictan otras disposiciones generales sobre la contratación con recursos públicos, 46.691 Diario Oficial, 16 de julio de 2007. Disponible en: http://www.secretariasenado.gov.co/senado/basedoc/ ley_1150_2007.html

Colombia, Ley 1340 de 2009, por medio de la cual se dictan normas en materia de protección de la competencia, 47.420 Diario Oficial, 24 de julio de 2009. Disponible en: http://www.secretariasenado.gov.co/senado/basedoc/ley_1340_2009.html

Colombia, Ley 1437 de 2011, por la cual se expide el Código de Procedimiento Administrativo y de lo Contencioso Administrativo, 47.956 Diario Oficial, 18 de enero de 2011. Disponible en: http://www.secretariasenado.gov.co/senado/ basedoc/ley_1437_2011.html

Colombia, Ley 1474 de 2011, por la cual se dictan normas orientadas a fortalecer los mecanismos de prevención, investigación y sanción de actos de corrupción y la efectividad del control de la gestión pública, Estatuto Anticorrupción, 48.128 Diario Oficial, 12 de julio de 2011. Disponible en: http://www.secretariasenado. gov.co/senado/basedoc/ley_1474_2011.html

Colombia, Proyecto de ley 038 de 2015, por el cual se introducen modificaciones al régimen de protección de la competencia, a las funciones de la Superintendencia de Industria y Comercio, y se dictan otras disposiciones. Disponible en: http:// www.sic.gov.co/drupal/sites/default/files/files/PROYECTO_DE_LEY\%20_ DE\%20_COMPETENCIA.pdf 


\section{Otros documentos}

Colombia, Consejo Privado de Competitividad, Informe Nacional de Competitividad 2013-2014 (Consejo Privado de Competitividad, Bogotá, 2013). Disponible en: http://www.compite.com.co/site/wp-content/uploads/2013/11/CPC_INC20132014-Informe.pdf

Comisión Europea, Comunicación de la Comisión. Directrices relativas a la aplicación del apartado 3 del artículo 81 del Tratado, C 101 Diario Oficial de la Unión Europea, 97-118, 27 de abril de 2004. Disponible en: http://eur-lex.europa.eu/LexUriServ/ LexUriServ.do?uri=CELEX:52004XC0427(07):ES:HTML

Comisión Europea, Comunicación de la Comisión relativa a la dispensa del pago de las multas y la reducción de su importe en casos de cártel, C 298 Diario Oficial de la Unión Europea, 17-22, 8 de diciembre de 2006. Disponible en: http://www. juntadeandalucia.es/defensacompetencia/sites/all/themes/competencia/files/ $\mathrm{pdfs} / 26 . \mathrm{pdf}$

España, Comisión Nacional de la Competencia, CNC, Guía sobre Contratación Pública y Competencia (Comisión Nacional de la Competencia, CNC, Madrid, 2011). Disponible en: www.cncompetencia.es, http://www.cnmc.es/Portals/0/Ficheros/ Promocion/Guias_y_recomendaciones/GUIA_CONTRATACION_v4.pdf

Estados Unidos, Department of Justice, Antitrust Division, Price Fixing, Bid Rigging, and Market Allocation Schemes: What They Are and What to Look For. An Antitrust Primer. Disponible en: http://www.justice.gov/atr/public/guidelines/211578.pdf

Gómez-Lee, Iván Darío, Contratación visible, Manual para un buen control de recursos en la contratación pública (Auditoría General de la República, Procuraduría General de la Nación, Instituto de Estudios del Ministerio Público, IEMP, Bogotá, 2010). Disponible en: http://www.auditoria.gov.co/Biblioteca_documental/OEE/ AGRP11-Manual_contratacion_visible_vl.pdf

Organización de las Naciones Unidas, ONU, La politica de la competencia y las adquisiciones del sector público (Conferencia de las Naciones Unidas sobre Comercio y Desarrollo, Junta de Comercio y Desarrollo, Comisión de Comercio y Desarrollo, Grupo Intergubernamental de Expertos en Derecho y Política de la Competencia, 12 período de sesiones, Ginebra, 9 a 11 de julio de 2012). Disponible en: http://unctad.org/meetings/es/SessionalDocuments/ciclpd14_sp.pdf

Organización para la Cooperación y el Desarrollo Económicos, OCDE, The Size of Government Procurement Markets (2011). Disponible en: http://www.oecd.org/ newsroom/archives/1845927.pdf

Organización para la Cooperación y el Desarrollo Económicos, OCDE, Lineamientos para combatir la colusión entre oferentes en licitaciones públicas (febrero de 2009). Disponible en: www.oecd.org, http://www.oecd.org/daf/competition/ cartels/42761715.pdf

Organización para la Cooperación y el Desarrollo Económicos, OCDE, Fiscalía Nacional Económica de Chile, Guía OCDE para combatir la colusión entre oferentes en licitaciones de abastecimiento público (Fiscalía Nacional Económica de Chile, OECD, 2009). Versión no oficial en español disponible en: http://www.coprocom. go.cr/documentos/seminarios/guia_ocde_combatir_colusion_licitaciones.pdf, versión en inglés: http://www.oecd.org/competition/cartels/42851044.pdf 
Organización para la Cooperación y el Desarrollo Económicos, OCDE, Foro Latinoamericano de Competencia, Sesión III, Mejorando la eficacia en las licitaciones públicas: combatiendo la colusión y la corrupción, Documento Base, DAF/COMP/LACF(2012)7, 18 al 19 de septiembre de 2012, República Dominicana, 5. Disponible en: http://www.oecd.org/officialdocuments/public displaydocumentpdf/?cote $=\mathrm{DAF} / \mathrm{COMP} / \mathrm{LACF}(2012) 2 \&$ docLanguage $=\mathrm{Es}$

Organización para la Cooperación y el Desarrollo Económicos, OCDE, Secretaría General, Memorándum de entendimiento entre la OCDE, la CFC y el IMSS para la implementación de las directrices del Comité de Competencia de la OCDE para combatir la colusión en las licitaciones para las compras públicas, Palabras de Ángel Gurría, Secretario General de la OCDE, México, 13 de enero de 2011. Disponible en: http://www.oecd.org/centrodemexico/medios/cooperacionocde-cfc-imss.htm

Superintendencia de Industria y Comercio de Colombia, Unión Europea, Guía práctica para combatir la colusión en las licitaciones (Superintendencia de Industria y Comercio de Colombia, Unión Europea, Delegación de la Unión Europea en Colombia, Bogotá, 2010). Disponible en: https://issuu.com/asteroide10/docs/ cartilla_colusiones_vf_para_publica

Transparencia por Colombia, Universidad Externado de Colombia, Cuarta encuesta nacional sobre prácticas contra el soborno de empresas colombianas, 23 Cuaderno de Transparencia (2015). Disponible en: http://transparenciacolombia.org.co/es/ noticias/resultados-de-la-cuarta-encuesta-nacional-sobre-practicas-contra-elsoborno-en-empresas-colombianas

Transparencia Internacional, Índice de Percepción de Corrupción 2014. Disponible en: http://www.transparency.org/cpi2014/results

Vanderbilt University, Latin American Public Opinion Project, LAPOP, Barómetro Global de la Corrupción 2014. Disponible en: http://www.vanderbilt.edu/lapop/

Whitehorn, Edward, Aumento de la competencia mediante la reducción de colusión en los procedimientos de licitación en Latinoamérica, V Reunión Anual del Foro Latinoamericano de la Competencia (Puebla, México, 20 de septiembre de 2007). Disponible en: www.oedc.org, http://www.oecd.org/officialdocuments/pu blicdisplaydocumentpdf/?cote $=\mathrm{DAF} / \mathrm{COMP} / \mathrm{LACF}(2007) 2 \&$ docLanguage $=\mathrm{En}$

\section{Jurisprudencia colombiana}

Consejo de Estado, Sala de lo Contencioso Administrativo, Sección Primera, expediente 2335, Sentencia del 7 de diciembre de 1993, consejero ponente Libardo RodríguezRodríguez.

Consejo de Estado, Sala de Consulta y Servicio Civil, Radicación 1454, Concepto del 16 de octubre de 2002, consejera ponente Susana Montes de Echeverri.

Consejo de Estado, Sala de lo Contencioso Administrativo, Sección Tercera, expediente 14652, Sentencia del 11 de septiembre de 2003, consejero ponente Ricardo Hoyos-Duque.

Consejo de Estado, Sala de lo Contencioso Administrativo, Sección Tercera, Radicación 30832, Sentencia del 30 de noviembre de 2006, consejero ponente Alier Hernández-Enríquez, Aclaración de voto: Ramiro Saavedra. 
Consejo de Estado, Sala de lo Contencioso Administrativo, Sección Tercera, expediente 17783, Sentencia del 4 de junio de 2008, consejera ponente Myriam Guerrero de Escobar.

Consejo de Estado, Sala de lo Contencioso Administrativo, Sección Primera, Proceso 00364, Caso ANDEVIP, Sentencia del 18 de enero de 2010, consejera ponente María Claudia Rojas-Lasso.

Consejo de Estado, Sala Plena de lo Contencioso Administrativo, expediente 38924, Sentencia del 14 de febrero de 2011, consejero ponente Jaime Orlando SantofimioGamboa.

Corte Constitucional, Sentencia C-524-95, 16 de noviembre de 1995, magistrado ponente Carlos Gaviria-Díaz. Disponible en: http://www.corteconstitucional.gov.co/ relatoria/1995/C-524-95.htm

Corte Constitucional, Sentencia C-616-01, 13 de junio de 2001, magistrado ponente Rodrigo Escobar-Gil. Disponible en: http://www.corteconstitucional.gov.co/ relatoria/2001/c-616-01.htm

Corte Constitucional, Sentencia C-815-01, 2 de agosto de 2001, magistrado ponente Rodrigo Escobar-Gil. Disponible en: http://www.corteconstitucional.gov.co/ relatoria/2001/c-815-01.htm

Corte Constitucional, Sentencia C-475-04, 18 de mayo de 2004, magistrado ponente Marco Gerardo Monroy-Cabra. Disponible en: http://www.corteconstitucional. gov.co/relatoria/2004/c-475-04.htm

Corte Constitucional, Sentencia C-865-04, 7 de septiembre de 2004, magistrado ponente Rodrigo Escobar-Gil. Disponible en: http://www.corteconstitucional.gov.co/ relatoria/2004/c-865-04.htm

Corte Constitucional, Sentencia C-992-06, 29 de noviembre de 2006, magistrado ponente Álvaro Tafur-Galvis. Disponible en: http://www.corteconstitucional.gov.co/ relatoria/2006/c-992-06.htm

Corte Constitucional, Sentencia C-352-09, 20 de mayo de 2009, magistrado ponente Luis Ernesto Vargas-Silva. Disponible en: http://www.corteconstitucional.gov. co/relatoria/2009/c-352-09.htm

Corte Constitucional, Sentencia C-228-10, 24 de marzo de 2010, magistrado ponente Luis Ernesto Vargas-Silva. Disponible en: http://www.corteconstitucional.gov. co/relatoria/2010/c-228-10.htm

Corte Constitucional, Sentencia C-263-11, 6 de abril de 2011, magistrado ponente Jorge Ignacio Pretelt-Chaljub. Disponible en: http://www.corteconstitucional.gov.co/ relatoria/2011/c-263-11.htm

Corte Constitucional, Sentencia C-368-12, 16 de mayo de 2012, magistrado ponente Luis Ernesto Vargas-Silva. Disponible en: http://www.corteconstitucional.gov. co/relatoria/2012/c-368-12.htm

Corte Constitucional, Sentencia T-145-93, 21 de abril de 1993, magistrado ponente Eduardo Cifuentes-Muñoz. Disponible en: http://www.corteconstitucional.gov. co/relatoria/1993/t-145-93.htm

Corte Suprema de Justicia, Sala de Casación Civil, sentencia de revisión 007, Proceso 
3348, magistrado ponente Nicolás Bechara-Simancas, 26 de enero de 1995

Tribunal Administrativo del Tolima, Radicación No. 00006-2008, Sentencia del 22 de enero de 2010, magistrada ponente Susana Nelly Acosta-Prada.

\section{Resoluciones y conceptos}

Superintendencia de Industria y Comercio, Resolución 19924 de 2003.

Superintendencia de Industria y Comercio, Resolución 14540 de 2002.

Superintendencia de Industria y Comercio, Resolución 25798 de 2003.

Superintendencia de Industria y Comercio, Resolución 21596 de 2004.

Superintendencia de Industria y Comercio, Resolución 21822 de 2004.

Superintendencia de Industria y Comercio, Resolución 17499 de 2008.

Superintendencia de Industria y Comercio, Resolución 1055 de 2009.

Superintendencia de Industria y Comercio, Resolución 69716 de 2009.

Superintendencia de Industria y Comercio, Resolución 44008 de 2010

Superintendencia de Industria y Comercio, Resolución 47481 de 2010.

Superintendencia de Industria y Comercio, Resolución 24646 de 2011.

Superintendencia de Industria y Comercio, Resolución 49454 de 2011.

Superintendencia de Industria y Comercio, Resolución 55463 de 2011.

Superintendencia de Industria y Comercio, Resolución 64400 de 2011.

Superintendencia de Industria y Comercio, Resolución 30 de 2012.

Superintendencia de Industria y Comercio, Resolución 40901 de 2012.

Superintendencia de Industria y Comercio, Resolución 53979 de 2012.

Superintendencia de Industria y Comercio, Resolución 53991 de 2012.

Superintendencia de Industria y Comercio, Resolución 40875 de 2013.

Superintendencia de Industria y Comercio, Resolución 53914 de 2013.

Superintendencia de Industria y Comercio, Resoluciones 58917 y 43361 de 2013.

Superintendencia de Industria y Comercio, Resoluciones 54693 y 54695 de 2013.

Superintendencia de Industria y Comercio, Concepto 25057 del 21 de marzo de 2013.

Superintendencia de Industria y Comercio, Resoluciones 68972 de 2013.

Superintendencia de Industria y Comercio, Resolución 83037 de 2014.

Superintendencia de Industria y Comercio, Resolución 1959 de 2015.

Superintendencia de Industria y Comercio, Resolución 2065 de 2015.

Superintendencia de Industria y Comercio, Resolución 11963 de 2015. 


\section{Páginas web}

http://transparenciacolombia.org.co/

http://www.ibarra.legal/

www.auditoria.gov.co

www.centrocedec.org

www.colombiacompra.gov.co

www.compite.com.co

www.contratos.gov.co

www.corteconstitucional.gov.co

www.nera.com

www.oecd.org

www.secretariasenado.gov.co

www.sic.gov.co

www.tgdcompetencia.org

www.uexternado.edu.co

Www.yocomprocolombiano.com 
